ARTICLE

\title{
Efficient access to aliphatic esters by photocatalyzed alkoxycarbonylation of alkenes with alkyloxalyl chlorides
}

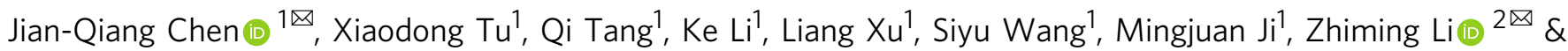
Jie Wu (1) 1,3,4凶

Aliphatic esters are essential constituents of biologically active compounds and versatile chemical intermediates for the synthesis of drugs. However, their preparation from readily available olefins remains challenging. Here, we report a strategy to access aliphatic esters from olefins through a photocatalyzed alkoxycarbonylation reaction. Alkyloxalyl chlorides, generated in situ from the corresponding alcohols and oxalyl chloride, are engaged as alkoxycarbonyl radical fragments under photoredox catalysis. This transformation tolerates a broad scope of electron-rich and electron-deficient olefins and provides the corresponding $\beta$ chloro esters in good yields. Additionally, a formal $\beta$-selective alkene alkoxycarbonylation is developed. Moreover, a variety of oxindole-3-acetates and furoindolines are prepared in good to excellent yields. A more concise formal synthesis of $( \pm)$-physovenine is accomplished as well. With these strategies, a wide range of natural-product-derived olefins and alkyloxalyl chlorides are also successfully employed.

\footnotetext{
${ }^{1}$ School of Pharmaceutical and Materials Engineering \& Institute for Advanced Studies, Taizhou University, Taizhou, China. ${ }^{2}$ Department of Chemistry, Fudan University, Shanghai, China. ${ }^{3}$ State Key Laboratory of Organometallic Chemistry, Shanghai Institute of Organic Chemistry, Chinese Academy of Sciences, Shanghai, China. ${ }^{4}$ School of Chemistry and Chemical Engineering, Henan Normal University, Xinxiang, China. $\varpi_{\text {email: chenjq@tzc.edu.cn; }}$ zmli@fudan.edu.cn; jie_wu@fudan.edu.cn
} 
A liphatic esters are highly valuable products and chemical intermediates. They are present in a broad range of important biologically active molecules (Fig. 1a) $)^{1-3}$ and among the most versatile intermediates in the step-economical and orthogonal synthesis of aliphatic acids, aliphatic amides, aldehydes, ketones, and alcohols. Traditionally, synthesis of aliphatic esters relies on the esterification of carboxylic acids, anhydrides, or acyl chlorides with alcohols. These approaches need the pre-installation of a carboxyl group in the substrate. A complementary and more versatile alternative can use alkenes as starting materials, which are readily available and abundant petrochemical feedstock starting materials and synthetic intermediates ${ }^{4}$. Alkoxycarbonylation reactions of alkenes, developed by Reppe in the 1950s, is the most significant industrial process under transition-metal catalysis (Fig. 1b) ${ }^{5}$. Based on the palladium-catalyzed alkoxycarbonylation of ethylene, the current most advanced industrial process (Lucie Alpha process) to methyl propionate is used on an industrial scale to produce $>300,000$ tons of products annually ${ }^{6}$. Although transition-metal-catalyzed alkoxycarbonylation reactions are powerful tools to synthesize esters, these processes rely on the use of high pressure of $\mathrm{CO}$, which often require specific equipment and safety precautions ${ }^{7}$. Additionally, application of these transformations is limited by the challenges associated with the regioselective alkoxycarbonylation of olefins as well as the harsh reaction conditions. Usually, a mixture of linear esters and branched esters is afforded $^{7}$. Thus, direct catalytic and regioselective synthesis of aliphatic ester derivatives from unactivated olefins under mild conditions remains an unsolved challenge in modern synthetic chemistry. It is clear that an efficient approach is needed to address the above issues in the regioselective alkoxycarbonylation process.

We expected that a free radical-based method involving the addition of an alkoxycabonyl radical to olefin might be an attractive and alternative strategy. With this strategy, the alkoxycarbonylation of olefins will provide the desirable linear esters. In general, alkoxycarbonyl radicals are generated most from the corresponding diethyl azodicarboxylate ${ }^{8}$, selenides ${ }^{9}$, and xanthates ${ }^{10}$. Additionally, alkoxycarbonyl radicals can be formed from carbazates ${ }^{11}$ and alkyl formates ${ }^{12}$ by treatment with stoichiometric amounts of oxidants. Recently, it was reported that alkoxycarbonyl radicals could be produced by photoredoxcatalyzed fragmentation of methyl $\mathrm{N}$-phthalimidoyl oxalates (Fig. 1c) $^{13}$. These existing methods for generating alkoxycarbonyl radicals from alcohols require multistep synthetic procedures. Moreover, most of the reported examples dealt with structurally simple alkoxycarbonyl radicals ${ }^{12}$, while only a few reports exploiting complex alkoxycarbonyl radicals are described ${ }^{14}$.

It is well known that single-electron reduction of aroyl and sulfonyl chlorides by photocatalyst would provide aroyl ${ }^{15-17}$ and sulfonyl radicals ${ }^{18}$, respectively. In this work, we envisioned that it might be possible to identify a strategy for the generation of alkoxycarbonyl radicals from the corresponding acyl chloride via photoredox catalysis (Fig. 1d). A photocatalytic strategy to introduce both the desired ester group and a versatile electrophile at the $\beta$-position of ester group would be quite useful for the preparation of significant compounds, due to the complementary reactivity of the esters. To the best of our knowledge, the selective alkoxycarbonylchlorination of alkenes leading to $\beta$-chloro esters from alkyloxalyl chlorides has not been explored yet.

\section{Results}

Reaction optimization. To verify the feasibility of this freeradical alkoxycarbonylchlorination strategy, ethyl chloroformate (2a') was used as the alkoxycarbonyl radical source. Unfortunately, none of the target product 3a was obtained when a mixture of 4-vinyl-1,1'-biphenyl (1a), ethyl chloroformate (2a'), 2,6lutidine and $\operatorname{Ir}(\text { ppy })_{3}$ in acetonitrile at $40{ }^{\circ} \mathrm{C}$ was irradiated with blue light-emitting diodes (LEDs) for $24 \mathrm{~h}$ (Table 1, entry 1 ). The failure of this result might be rationalized by the difficulty of promoting single-electron reduction of chloroformate because of its lower reduction potential. After careful investigation, we found that the readily available and inexpensive ethyl chlorooxoacetate (2a) $[0.5 \mathrm{~kg} / \$ 227$ : supplier: Sigma-Aldrich and $0.5 \mathrm{~kg} / \$ 202$ : supplier: TCI] was an ideal alkoxycarbonyl radical precursor. This

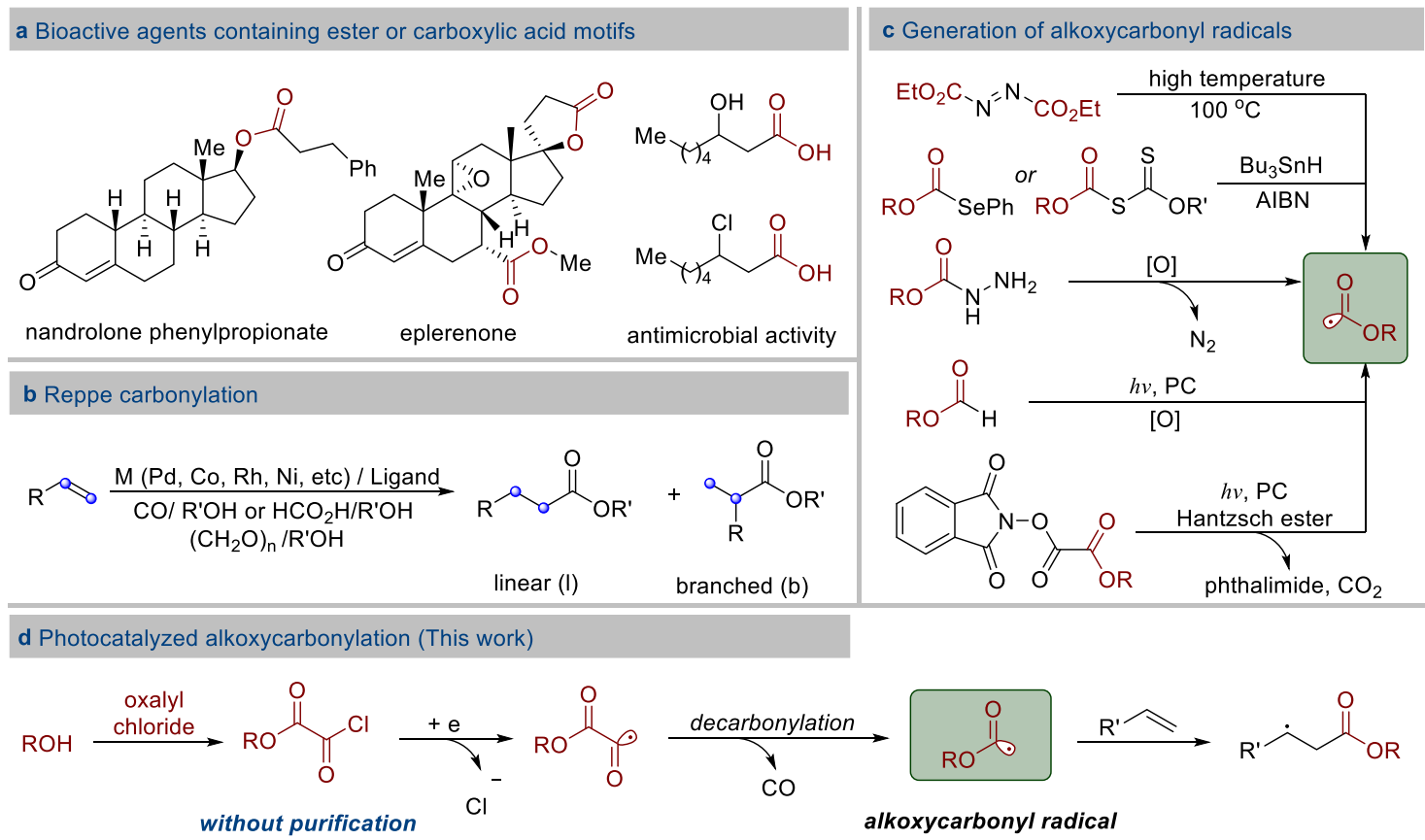

Fig. 1 Bioactive carboxylic derivatives and approaches for their synthesis. a Bioactive agents containing ester or carboxylic motifs. b Reppe carbonylation. c Generation of alkoxycarbonyl radicals. d This study. 
Table 1 Initial studies for the photoinduced reaction of 4-vinyl-1,1'-biphenyl 1a with ethyl chlorooxoacetate $2 a^{a}$.

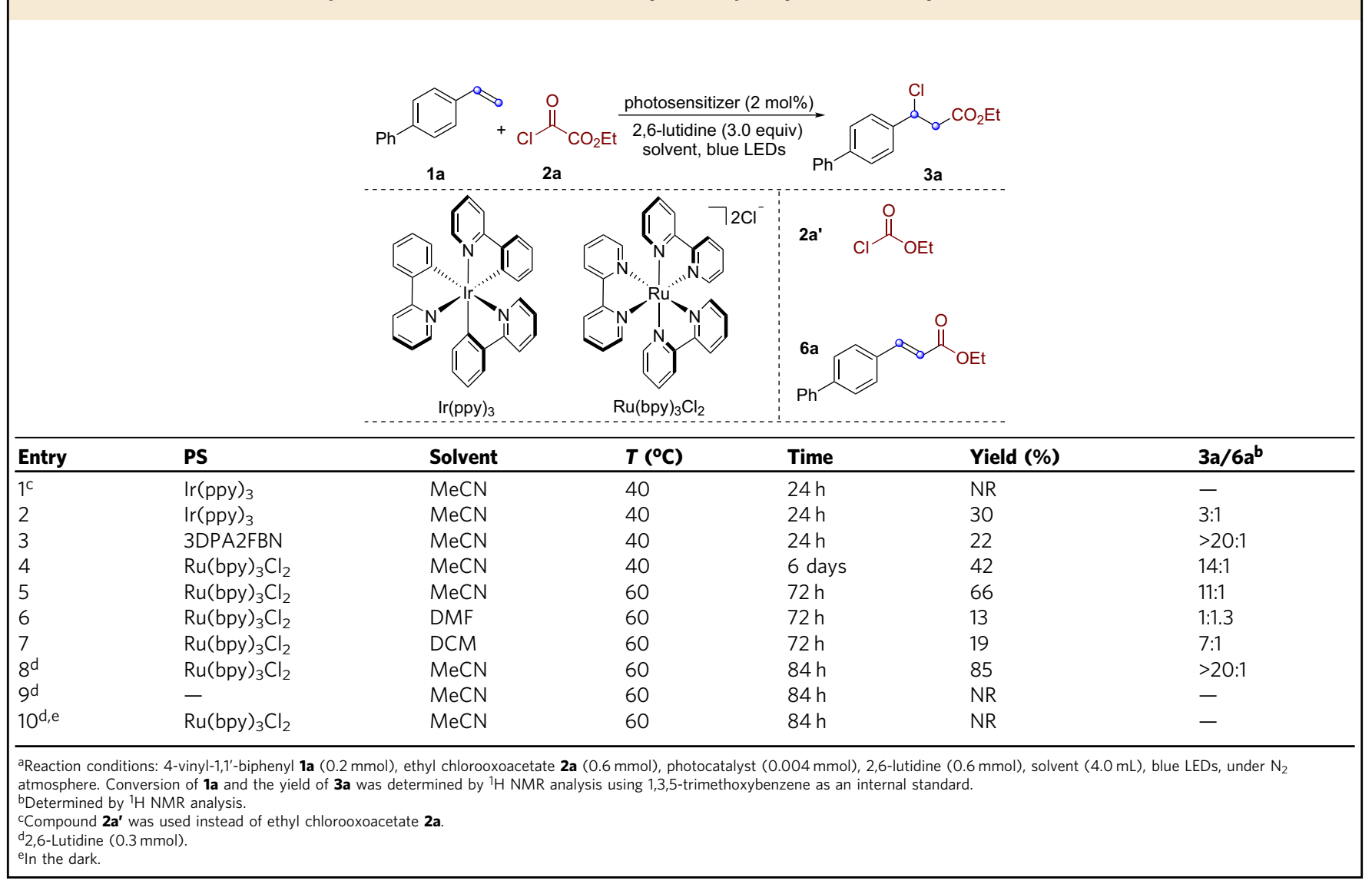

chlorooxoacetate might be readily reduced by the excited state of photocatalyst $\operatorname{Ir}(\mathrm{ppy})_{3}$ to generate alkoxycarbonyl radical through CO extrusion. As shown in entry 2 (Table 1), the linear product 3a was observed ${ }^{19}$, accompanied by the appearance of by-product $\mathbf{6 a}(10 \%$ yield) when ethyl chlorooxoacetate (2a) was used instead of ethyl chloroformate (2a'). This transformation proceeded with excellent regioselectivity and gave rise to the direct formation of linear ester 3a (the branch isomer could not be found by ${ }^{1} \mathrm{H}$ nuclear magnetic resonance (NMR)) under the operationally simple conditions. Additionally, examination of photosensitizers revealed that $\mathrm{Ru}(\mathrm{bpy})_{3} \mathrm{Cl}_{2}$ produced a better yield (entry 4 ); however, the reaction took much longer time for completion. To further improve the yield of alkoxycarbonylchlorination product of ethyl 3-([1,1'-biphenyl]-4-yl)-3-chloropropanoate (3a), the reaction temperature was increased, and the yield was slightly higher (66\%, entry 5 in Table 1). Evaluation of different solvents showed that acetonitrile was the best choice in this transformation (entries 5-7). Notably, $\alpha, \beta$-unsaturated ester compound $6 \mathbf{a}$ was the major product when dimethylformamide (DMF) was used instead of acetonitrile. Interestingly, decreasing the amount of 2,6-lutidine led to a significantly improved yield and substrate (1a) was fully consumed (entry 8). As expected, visible light irradiation and photosensitizer were essential for this alkoxycarbonylchlorination reaction (entries 9-10).

Substrate scope of activated alkenes. With the optimized conditions in hands, the generality of this alkoxycarbonylchlorination reaction was then evaluated. As outlined in Fig. 2, a wide range of styrenes were efficiently workable in this protocol. For example, electron-neutral and electron-rich styrenes were all suitable substrates (3b-3d, 63-68\% yield). This photocatalyzed alkoxycarbonylchlorination strategy was effective as well for electron-deficient styrenes, as demonstrated by the installation of fluoro, chloro, bromo, ester, and aldehyde groups (3e-3i, 41-75\% yield). Furthermore, parachloromethyl styrene, which could be further functionalized through nucleophilic substitution reaction, gave rise to the target product $(\mathbf{3 j})$ in good yield. Moreover, 1- and 2-vinylnaphthalenes were found to be competent substrates (3k and 31, 63 and $83 \%$ yield, respectively). The efficiency of this process was not impeded by ortho-, meta-methyl, or fluorine substitutions on the aromatic rings (3m-3p, 40-63\% yield). A natural-product-derived styrene substrate was also coupled with high level of efficiency (3q, 62\% yield). This result further demonstrated the potential of employing native functionality to access structural analogs and to provide further functionalization.

Having demonstrated the capacity of activated alkenes in this alkoxycarbonylchlorination reaction, we next investigated the conversion of various alkyloxalyl chlorides. As shown in Fig. 2, the yield was decreased to $38 \%$ ( $3 \mathbf{b}$ vs. $3 \mathbf{r}$ ) when commercially available methyl oxalyl chloride was used as the alkoxycarbonyl radical precursor in the reaction with styrene. By raising the equivalent of methyl oxalyl chloride, the yield of $\mathbf{3 r}$ was increased from 38 to $54 \%$. We applied this strategy to the derivatization of alcohol-containing biologically active molecules. By treatment of the corresponding alcohols with oxalyl chloride in dry dichloromethane (DCM), alkyloxalyl chlorides generated in situ were employed directly in the photoredox protocol after removal of the excess amount of oxalyl chloride and DCM by vacuum distillation $^{20}$. Alkyloxalyl chlorides derived from primary and secondary alcohols were found to be successful in this alkoxycarbonylchlorination reaction. Chiral amino alcohol derivative reacted with styrene leading to product $3 \mathrm{~s}$ in $64 \%$ yield. 


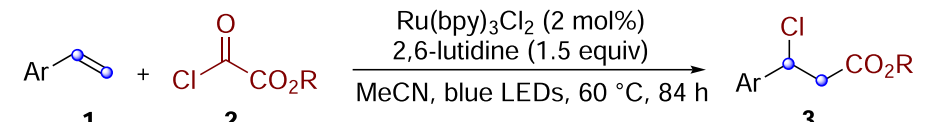

\section{Activated alkenes}<smiles>CCOC(=O)OC(Cl)c1ccccc1</smiles>

$3 a, 81 \%$ yield

3b, $65 \%$ yield<smiles>CCOC(=O)OC(Cl)c1ccc(C(C)(C)C)cc1</smiles><smiles>CCOC(=O)OC(Cl)c1ccc(F)cc1</smiles>

$3 e, 66 \%$ yield<smiles>CCOC(=O)OC(Cl)c1ccc(C)cc1</smiles>

3c, $63 \%$ yield<smiles>CCOC(=O)OC(Cl)c1ccc(Cl)cc1</smiles>

3f, $68 \%$ yield

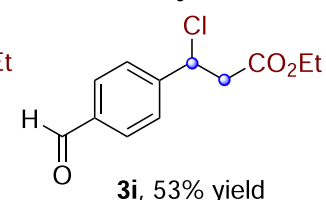<smiles>CCOC(=O)OCc1ccc(C(Cl)OC(=O)OCC)cc1C(Cl)c1cccc2ccccc12</smiles>
$3 \mathrm{j}, 62 \%$ yield

3k, $63 \%$ yield

$31,83 \%$ yield<smiles></smiles><smiles>CCOC(=O)OC(Cl)c1cccc(C)c1</smiles><smiles>CCOC(=O)OC(Cl)c1ccccc1F</smiles>

$3 \mathrm{~m}, 63 \%$ yield 3n, $61 \%$ yield 3o, $41 \%$ yield<smiles>CCOC(=O)OC(Cl)c1cccc(F)c1</smiles><smiles>CCOC(=O)OC(Cl)c1ccc2c(c1)CC[C@@H]1[C@@H]2CC[C@]2(C)C(=O)CC[C@@H]12</smiles>

$3 p, 40 \%$ yield $3 q, 62 \%$ yield, from estrone

\section{Alkyloxalyl chlorides}

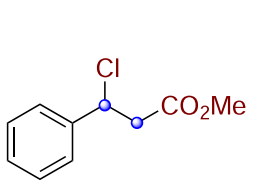<smiles>O=C(OCC(Cc1ccccc1)N1C(=O)c2ccccc2C1=O)OC(Cl)c1ccccc1</smiles>

3s, $64 \%$ yield, $1: 1 \mathrm{dr}$

$3 r, 38 \%$ yield; ( $54 \%$ yield)<smiles>CC1(C)C2CCC1(C)C(OC(=O)OC(Cl)c1ccccc1)C2</smiles>

3t, $87 \%$ yield, $1: 1 \mathrm{dr}$ (from (-)-borneol)<smiles>CC12CCC(OC(=O)OC(Cl)c3ccccc3)C[C@H]1CC[C@@H](C1CCCC3(C)C(=O)CCC13C)C2</smiles>

3u, $45 \%$ yield, $1: 1 \mathrm{dr}^{\mathrm{b}}$, (from androsterone)<smiles>[M]C12CCC(OC(=O)OC(Cl)c3ccccc3)CC1CC[C@H]1C2CCC2(C)C(C(C)CCCC(C)CC)CCC12</smiles>

$3 v, 69 \%$ yield, $2: 1 \mathrm{dr}^{\mathrm{b}}$, (from $\beta$-cholestanol)<smiles>CC(C)C1CCC(C(C)C)[C@H](OC(=O)OC(Cl)c2ccccc2)C1</smiles>

$3 w, 68 \%$ yield, $1: 1 \mathrm{dr}$ (from menthol)

Fig. 2 Alkoxycarbonylchlorination with activated alkenes. Reaction conditions: activated alkene $\mathbf{1}(0.2 \mathrm{mmol})$, alkyloxalyl chloride $\mathbf{2}$ ( $0.6 \mathrm{mmol})$, $\mathrm{Ru}(\text { bpy })_{3} \mathrm{Cl}_{2}(2 \mathrm{~mol} \%), 2,6$-lutidine $(0.3 \mathrm{mmol})$, anhydrous $\mathrm{MeCN}(4.0 \mathrm{~mL})$, blue LEDs, $60{ }^{\circ} \mathrm{C}, 84 \mathrm{~h}$, under $\mathrm{N}_{2}$ atmosphere. Isolated yields. The dr values were determined by ${ }^{1} \mathrm{H}$ NMR analysis. ${ }^{a}$ Alkyloxalyl chloride $2(1.0 \mathrm{mmol})$. betermined by HPLC analysis. 
Additionally, this transformation was insensitive to steric hindrance around the site of alkoxycarbonyl radical $(3 \mathbf{t}-\mathbf{3 w}$, $45-87 \%$ yield). For example, alkyloxalyl chloride derived from (-)-borneol provided the desired product (3t) in $87 \%$ yield. Notably, chlorooxoacetates derived from other nature products, including androsterone (product $3 \mathbf{u}, 45 \%$ yield), $\beta$-cholestanol (product 3v, 69\% yield) and menthol (product 3w, 68\% yield), were workable as well. In general, reactions of secondary alkyl chlorooxoacetates gave better yields than those of primary alkyl chlorooxoacetates. This result might be rationalized by the slower decay rate of secondary alkoxycarbonyl radicals with alkyloxalyl chlorides $(\tau=4.4 \mu \mathrm{s}$ for $i$-propylcarbonyloxy radical vs. $\tau=2.4 \mu \mathrm{s}$ for ethylcarbonyloxy radical in $\left.\mathrm{CCl}_{4}\right)^{21,22}$.

Reaction condition development. Encouraged by the results described above, we subsequently explored the transformation of various unactivated alkenes (Supplementary Table 2). The reaction of non-conjugated alkene (but-3-en-1-ylbenzene 4a) failed to provide the corresponding product under the optimal conditions. However, the formation of desired $\beta$-chloro ester product $\mathbf{5 a}$ was observed when $\operatorname{Ir}(\mathrm{ppy})_{3}$ was employed. A better result was obtained when the reaction was performed at $30^{\circ} \mathrm{C}$. By raising the equivalents of photosensitizer $\operatorname{Ir}(\mathrm{ppy})_{3}$ and alkoxycabonyl radical source $2 \mathrm{a}$, the yield of this reaction was increased from 44 to $74 \%$.

Substrate scope of unactivated alkenes. On the basis of the above-optimized conditions, we next explored the reaction scope with diverse unactivated alkenes. As illustrated in Fig. 3, a wide range of unactivated alkenes coupled with chlorooxoacetate $\mathbf{2 a}$ efficiently, giving rise to the corresponding products. Transformation of long-chain $\alpha$-olefins produced the desired compounds $\mathbf{5 b}-\mathbf{5 e}$ in reasonable yields (53-69\%) with complete regiocontrol. Remarkably, hydrolysis of ethyl $\beta$-chlorooctanoate $\mathbf{5 b}$ promoted by $\mathrm{HCl}$ would provide an antibacterial compound ${ }^{3}$. Cetylates and stearates are privileged motifs encountered across the molecular sciences $^{23}$, particularly in food chemistry ${ }^{23}$, medicinal chemistry $^{24}$, flavor, and fragrance industry ${ }^{25}$. Reaction of 1 -pentadecene or 1-heptadecene would afford the addition product of ethyl $\beta$-chlorocetylate $\mathbf{5 d}$ or ethyl $\beta$-chlorostearate $5 \mathbf{e}$ in moderate yields, respectively. Moreover, a versatile electrophile at the $\beta$-position of ester would certainly accelerate the synthesis and discovery of bioactive molecules. More nucleophilic 1,1-disubstituted alkenes could participate smoothly in this transformation, affording the corresponding product $\mathbf{5 f}$ in $78 \%$ yield. It was found that a striking feature of this reaction was the exclusive formation of $\beta$-chloro esters without any undesired rearranged products, even in cases where benzyl, cyclohexyl, and tert-butyl were present in the $\alpha$-position of double bond. Aside from various carbon scaffolds, some functional groups were found to be tolerated under the conditions, such as esters (5j and $\mathbf{5 k}$ ), ketones (5l and $5 \mathrm{~m}$ ), and amide (5o). Reaction of tri-substituted alkene derived from cholesterol produced the corresponding product $5 \mathbf{n}$ in an unoptimized $21 \%$ yield, along with $40 \%$ of unreacted starting material recovered. Another aspect worth mentioning here was the excellent diastereoselectivity (>20:1 dr) and regioselectivity of this transformation. Furthermore, electron-deficient olefin was entirely converted into the expected $\beta$-chloro product 5o. In all cases, only one regioisomer was obtained, making this reaction fully regioselective.

Since 1-tetralone moiety is widely found in the core structure of natural products ${ }^{26}$, organic synthetic intermediates ${ }^{27}$, and bioactive compounds ${ }^{28,29}$, much attention has focused on the synthesis of 1-tetralone derivatives. Therefore, the above method was applied to the preparation of 1-tetralone derivatives. Several 1-tetralone derivatives (5') were prepared in moderate yields through a radical alkoxycarbonylation/cyclization with 1-arylpent-4-en-1-ones under the same reaction conditions. This convenient method described above will be potentially useful for the synthesis of bioactive compounds containing 1-tetralone moiety.

Synthesis of $\boldsymbol{\alpha}, \boldsymbol{\beta}$-unsaturated esters. Late-stage carbon-hydrogen bond functionalization of pharmacologically active compounds is a remarkable strategy for the discovery of functional compounds because it avoids laborious de novo construction of analogs, increases the efficiency of structure-activity relationship investigation, and provides candidates that might have never been explored ${ }^{30}$. Since $\beta$-chloro esters generated from direct alkoxycarbonylchlorination could undergo $\mathrm{HCl}$ elimination upon workup leading to $\alpha, \beta$-unsaturated esters ${ }^{31}$, we envisioned that this formal $\beta$-selective alkenyl $\mathrm{C}-\mathrm{H}$ alkoxycarbonylation could be accomplished and quite appealing. Additionally, $\alpha, \beta$-unsaturated esters are key components of synthetic building blocks, pharmaceuticals, and natural products ${ }^{32-34}$. Thus, synthesis of $\alpha, \beta$ unsaturated esters remains an actual interesting task in the context of development of improved synthetic methodologies ${ }^{35}$. As illustrated in Fig. 4, by treatment of alkenes and ethyl chlorooxoacetate $\mathbf{2 a}$ under the optimal conditions, followed by elimination in the presence of excess amount of 1,8-diazabicyclo[5.4.0] undec-7-ene (DBU) at $25^{\circ} \mathrm{C}$ for $30 \mathrm{~min}, \alpha, \beta$-unsaturated esters 6 were obtained with high levels of chemoselectivity, regioselectivity, and stereoselectivity. A wide range of olefins could participate in this transformation, affording the corresponding $\alpha, \beta$-unsaturated esters. Various electron-neutral, electron-rich, and electron-poor styrenes were viable substrates (6a-6j, 47-75\% yield). 1,1-Disubstituted aryl alkenes reacted with ethyl chlorooxoacetate $\mathbf{2 a}$ giving rise to the corresponding trisubstituted $\alpha, \beta$-unsaturated esters in moderate yields (6k-6l, 54-59\% yield). Reaction of 3,4,5-trimethoxystyrene could produce the desired cinnamic ester derivative $\mathbf{6 m}$. To demonstrate the amenability of this alkoxycarbonylation process to late-stage application, bexarotene ${ }^{36}$ analog was subjected to the standard conditions and the corresponding alkoxycarbonylation product $\mathbf{6 n}$ was obtained in $57 \%$ yield. Additionally, unactivated alkenes could be workable as well, affording the desired products $(\mathbf{6 o}$ and $\mathbf{6 p})$ in moderate yields.

Synthesis of oxindole-3-acetates. We next explored the generality of the decarbonylative alkoxycarbonylation/cyclization protocol. As shown in Fig. 5, it was found that a broad range of $\mathrm{N}$-arylacrylamide derivatives and alkyloxalyl chlorides were suitable substrates in this transformation. A number of $\mathrm{N}$-arylacrylamides bearing both electron-rich and electron-poor substituents in the aromatic ring underwent alkoxycarbonylation/ cyclization with ethyl chlorooxoacetate 2a leading to the corresponding products in good-to-excellent yields. Notably, reaction of antetrahydroquinoline or tetrahydrobenz-azepine derivative afforded the desired tricyclic product $8 \mathbf{e}$ or $\mathbf{8 f}$ in 91 and $90 \%$ yield, respectively. Furthermore, $N$-arylacrylamide with a naphthalene substituent on the nitrogen reacted with ethyl chlorooxoacetate 2a smoothly, providing the corresponding oxindole-3acetate $\mathbf{8 1}$ in $83 \%$ yield. $\mathrm{N}$-arylacrylamides with ethyl-, isopropyl-, and benzyl-protecting groups on the nitrogen atom proceeded well, affording the substituted products in good yields $(\mathbf{8 m}-\mathbf{8 o}$, $72-80 \%$ yield). Additionally, acrylamide with a benzyl group at the $\alpha$-position could convert into the desired product $\mathbf{8 p}$ in $91 \%$ yield. To demonstrate the practicability of this photoredox process, a gram-scale experiment was carried out, which provided the corresponding oxindole-3-acetate $\mathbf{8 a}$ in $77 \%$ yield $(1.53 \mathrm{~g})$. However, transformations of unprotected $N$-arylacrylamide, 


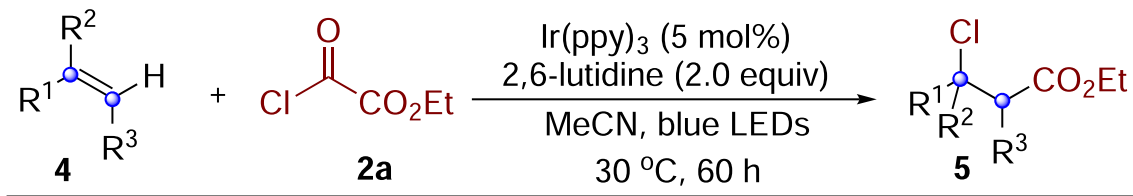

Unactivated alkenes<smiles>CCOC(=O)OC(Cl)CCc1ccccc1</smiles><smiles>CCOC(=O)OC(Cl)=[W]C</smiles><smiles>CCC(Cl)CC(=O)O</smiles><smiles>CCOC(OCC)OC(=[14CH])Cl</smiles>

$5 \mathbf{b}, 65 \%$ yield

antimicrobial activity

5c, $69 \%$ yield<smiles>CCOC(=O)OC(Cl)[Y17](C)C</smiles><smiles>CCOC(=O)OC(Cl)=[W]C</smiles>$$
\text { 5d, } 57 \% \text { yield }
$$

$5 e, 53 \%$ yield$$
\sim \sigma_{\sigma^{\mathrm{d}}}^{\mathrm{Cl}} \mathrm{CO}_{2} \mathrm{Et}
$$
ethyl $\beta$-chlorocetylate ethyl $\beta$-chlorostearate

\section{5f, $78 \%$ yield}<smiles>CCOC(=O)OC(Cl)Cc1ccccc1</smiles>

$5 g, 42 \%$ yield<smiles>CCOC(=O)OC(Cl)C1CCCCC1</smiles><smiles>CCOC(=O)OC(Cl)C(=O)OCCOC(=O)C(Cl)c1ccccc1</smiles>
$5 i, 43 \%$ yield
$5 j, 45 \%$ yield
5 k, $40 \%$ yield<smiles>CCOC(=O)OC(Cl)CCC(=O)c1ccc(OC(F)(F)F)cc1</smiles>

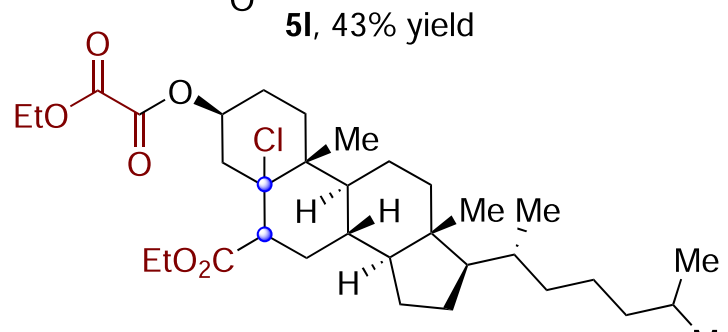<smiles>CCOC(=O)OC(Cl)CCC(=O)C1CCCCC1</smiles>

$5 n^{a}, 21 \%$ yield, $d r>20: 1$ (from cholesterol)<smiles>CCOC(=O)OC(C)(Cl)C(=O)N1CCc2ccccc21</smiles>
$\mathrm{Me}$

5o, $44 \%$ yield

\section{Synthesis of 1-tetralone derivatives}<smiles>CCOC(=O)OC1CCC(=O)c2c(C)cccc21</smiles>

$\mathbf{5 a}$ ', $43 \%$ yield<smiles>CCOC(=O)OC1CCC(=O)c2ccc(-c3ccccc3)cc21</smiles>

$5 \mathbf{b}^{\prime}, 40 \%$ yield<smiles></smiles>

$5 c^{\prime}, 51 \%$ yield

Fig. 3 Alkoxycarbonylchlorination with unactivated alkenes. Reaction conditions: unactivated alkene $\mathbf{4}(0.2 \mathrm{mmol})$, ethyl chlorooxoacetate $\mathbf{2 a}$ (1.6 mmol), $\operatorname{Ir}(\text { ppy })_{3}(5 \mathrm{~mol} \%), 2,6$-lutidine $(0.4 \mathrm{mmol})$, anhydrous $\mathrm{MeCN}(4.0 \mathrm{~mL})$, blue LEDs, $30^{\circ} \mathrm{C}, 60 \mathrm{~h}$, under $\mathrm{N}_{2}$ atmosphere. Isolated yields. ${ }^{\text {aReaction time: }}$ $84 \mathrm{~h}$. The $\mathrm{dr}$ value was determined by ${ }^{1} \mathrm{H}$ NMR analysis. 


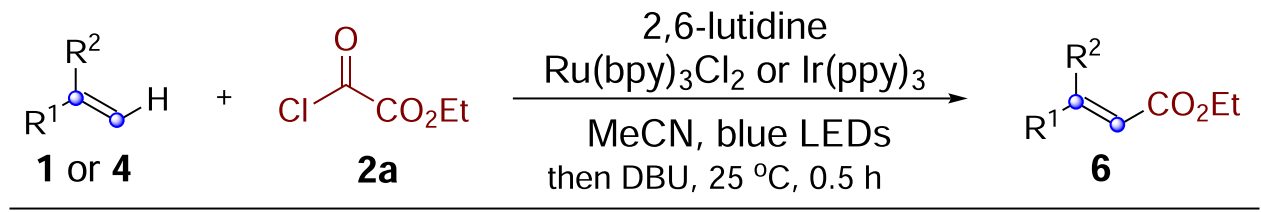<smiles>CCOC(=O)Oc1ccc(-c2ccccc2)cc1</smiles>

6a, $75 \%$ yield<smiles>CCOC(=O)Oc1ccccc1</smiles>

6b, $55 \%$ yield<smiles>CCOC(=O)c1ccc(C)cc1</smiles><smiles>CCOC(=O)c1ccc(C(C)(C)C)cc1</smiles>

6d, $59 \%$ yield<smiles>CCOC(=O)Oc1ccc(Cl)cc1</smiles>

$6 g, 50 \%$ yield<smiles>CCOC(=O)Oc1ccc2ccccc2c1</smiles>

6j, 56\% yield<smiles>CCOC(=O)c1cc(OC)c(OC)c(OC)c1</smiles>

$6 m, 49 \%$ yield<smiles>CCOC(=O)OCCc1ccccc1</smiles>

$60,58 \%$ yield<smiles>CCOC(=O)COc1ccc(OC)cc1</smiles>

$6 e, 49 \%$ yield
$6 c, 51 \%$ yield<smiles>CCOC(=O)Oc1ccc(F)cc1</smiles>

6f, $47 \%$ yield<smiles>CCOC(=O)Oc1ccc(Br)cc1</smiles>

$6 \mathrm{~h}, 52 \%$ yield<smiles>CCOC(=O)Oc1ccc(CCl)cc1</smiles>

$6 i, 51 \%$ yield<smiles>CCOC(=O)C(C)c1ccc(Cl)cc1</smiles><smiles>CCOC(=O)C=C(c1ccccc1)c1ccccc1</smiles>

6 k, $54 \%$ yield

$6 \mathrm{I}, 59 \%$ yield

6n, $57 \%$ yield (from bexarotene)<smiles>CCOC(=O)OCCCCCCCCCC(=O)OC</smiles>

6p, $33 \%$ yield

Fig. 4 Synthesis of $\boldsymbol{\alpha}, \boldsymbol{\beta}$-unsaturated esters. Isolated yields based on alkene $\mathbf{1}$ or $\mathbf{4}$

mono-substituted olefin $\left(R^{3}=H\right)$, and indoline derivative were not successful.

Subsequently, reactions of various alkyloxalyl chlorides were investigated under the standard conditions. The yield of alkoxycarbonylation/cyclization product was slightly diminished (8q vs. 8a) when methyl oxalyl chloride was used instead of ethyl chlorooxoacetate 2a. Alkyloxalyl chlorides derived from primary alcohols were found to be successful in this conversion. For example, reaction of alkyloxalyl chloride derived from 4-phenyl1-butanol provided the desired product in quantitative yield $(\mathbf{8 r}$, $99 \%$ yield). The long-chain alkyloxalyl chloride derivative was also an effective alkoxycarbonyl radical source, and the corresponding product $\mathbf{8 s}$ was furnished in $85 \%$ yield. To further demonstrate the advantage of this conversion, we applied this strategy to the derivatization of alcohol-containing biologically active molecules. A series of chiral secondary alcohols were examined, and the representative examples are shown in Fig. 5. It is noteworthy that the corresponding chiral secondary alkoxycarbonyl radical intermediates could readily convert into the desired products without any decarboxylated products $(\mathbf{8 t}-\mathbf{8 y}$, $58-84 \%$ yields). Moreover, the reaction was insensitive to steric hindrance around the site of alkoxycarbonyl radicals $(\mathbf{8 t}-\mathbf{8 v}$, $61-84 \%$ yield). The transformations proceeded efficiently as well when $\beta$-cholestanol (product $\mathbf{8 w}, 81 \%$ yield), androsterone (product $\mathbf{8 x}, 81 \%$ yield), and cholesterol-derived (product $\mathbf{8 y}$, $58 \%$ yield) alkyloxalyl chlorides were used. Excellent diastereoselectivity ( $>20: 1 \mathrm{dr}$ ) was observed for $\beta$-cholestanol substrate. We speculated that the unique three-dimensional structure of $\beta$ cholestanol might influence the following cyclization reaction. Chiral amino alcohol derivatives could also be applied to the synthesis of oxindole-3-acetates (8z-8ad, $67-82 \%$ yield). These experiments demonstrated that this strategy was compatible with 
$\underset{\mathrm{ROH}}{\stackrel{\text { oxalyl chloride }}{\text { without purification }}}$ RO

alcohol

2, alkyloxalyl chloride

8, oxindole-3-acetate

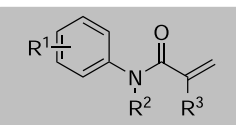

7, $\mathrm{N}$-arylacrylamide

\section{N-Arylacrylamide scope}

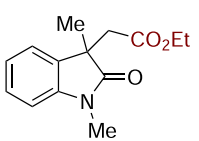

8a, $93 \%$ yield mmol: $77 \%$ yield $(1.53 \mathrm{~g})$

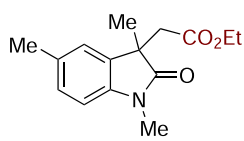

8b, $80 \%$ yield<smiles>CCOCCC1(C)C(=O)N(C)c2ccc(OC)cc21</smiles>

8c, $74 \%$ yield $^{a}$<smiles>CCOCCC1(C)C(=O)N(C)c2ccc(C(C)(C)C)cc21</smiles>

8d, $89 \%$ yield<smiles>CCOC(=O)CC1(C)C(=O)N2CCCc3cccc1c32</smiles>

$\mathbf{8 e}, 91 \%$ yield

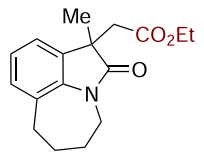

8f, $90 \%$ yield<smiles>CCOC(=O)CC1(C)C(=O)N(C)c2ccc(C#N)cc21</smiles>

Me<smiles>CCOC(=O)CC1(C)C(=O)N(C)c2ccc(C(F)(F)F)cc21</smiles>

8h, $71 \%$ yield

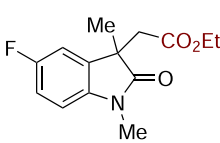

Me<smiles>CCOC(=O)CC1(C)C(=O)N(C)c2ccc(Cl)cc21</smiles>

Me

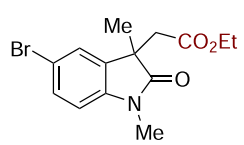

8k, $79 \%$ yield<smiles>CCOC(=O)CC1(C)C(=O)N(C)c2c1ccc1ccccc21</smiles>

8j, 77\% yield<smiles>CCOC(=O)CC1(C)C(=O)N(c2ccccc2)c2ccccc21</smiles>

$\mathrm{Bn}$<smiles>CCOC(=O)CC1(Br)C(=O)N(C)c2ccccc21</smiles>

Me<smiles>C=C(C)C(=O)Nc1ccccc1</smiles><smiles>C=CC(=O)N(c1ccccc1)[N+](=O)[O-]</smiles>

$8 \mathrm{~m}, 79 \%$ yield

8 n, $80 \%$ yield

8o, $72 \%$ yield

$8 p, 91 \%$ yield

Unsuccessful substrates

\section{Alkyloxalyl chloride scope}

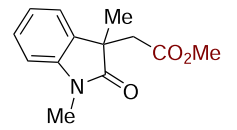

$\mathbf{8 q}, 88 \%$ yield<smiles>CN1C(=O)C(C)(CC(=O)OC2(C)C3(C)CCC(C3)C2(C)C)c2ccccc21</smiles>

$8 u, 61 \%$ yield, $1.2: 1 \mathrm{dr}$ (from (+)-fenchol)

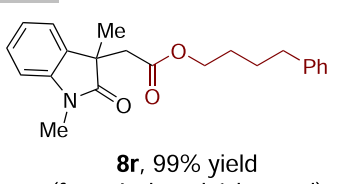
(from 4-phenyl-1-butanol)<smiles>CCCCCCCCCCCCCCCCOC(=O)CC1(C)C(=O)N(C)c2ccccc21</smiles>
(from hexadecanol)

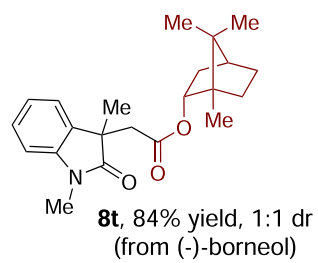<smiles>[M]C1CC[C@H](CC(C)C)C(OC(=O)CC2(C)C(=O)N(C)c3ccccc32)C1</smiles>

$\mathbf{8 v}, 70 \%$ yield, 1.3:1 dr (from menthol)

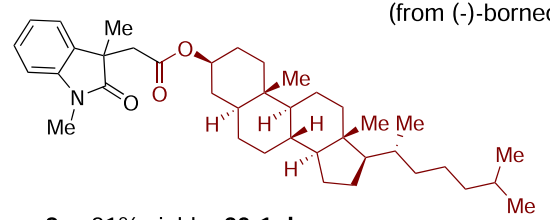

$8 w, 81 \%$ yield, $>20: 1 d r$ (from $\beta$-cholestanol)

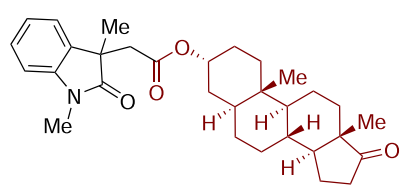

$\mathbf{8 x}, 81 \%$ yield, $1: 1 \mathrm{dr}$ (from androsterone)

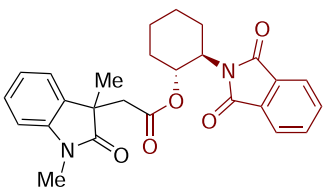

8ab, $81 \%$ yield, $1: 1 \mathrm{dr}$

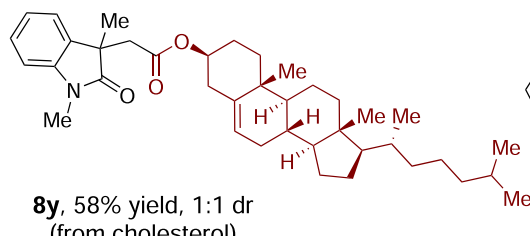

$8 y, 58 \%$ yield, $1: 1 \mathrm{dr}$
(from cholesterol)

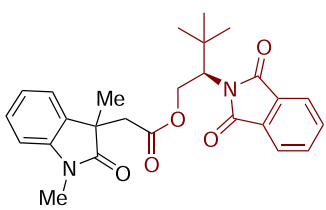

8ac, $67 \%$ yield, 1:1 dr

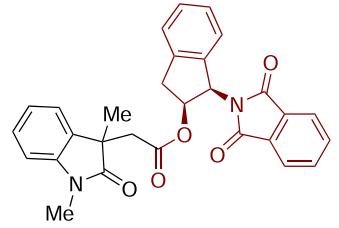

8ad, $72 \%$ yield, $1.1: 1 \mathrm{dr}$

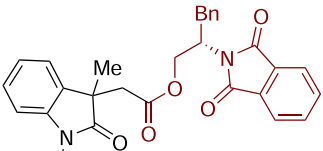

Mé

8 aa, $82 \%$ yield, $1: 1 \mathrm{dr}$
- No purification needed for alkyloxalyl chloride

Mild conditions
Easily available starting materials

Broad scope

Fig. 5 From alcohols to oxindole-3-acetates: substrate scope of the alkoxycarbonylation/cyclization reaction. Reaction conditions: $\mathrm{N}$-arylacrylamide 7 $(0.2 \mathrm{mmol})$, alkyloxalyl chloride $2(0.6 \mathrm{mmol}), \operatorname{Ir}(\mathrm{ppy})_{3}(2 \mathrm{~mol} \%), 2,6$-lutidine $(0.4 \mathrm{mmol})$, anhydrous DMF $(4.0 \mathrm{~mL})$, blue LEDs, $40{ }^{\circ} \mathrm{C}, 24 \mathrm{~h}, \mathrm{under} \mathrm{N}_{2}$ atmosphere. Yield of isolated product. The $\mathrm{dr}$ values were determined by ${ }^{1} \mathrm{H}$ NMR analysis. aReaction time: $48 \mathrm{~h}$. 
the functionalization of biologically active molecules bearing polar functional groups $(\mathbf{8 x}$ and $\mathbf{8 z}-\mathbf{8 a d})$. However, reactions of benzyl and tertiary alcohol derivatives failed to provide the corresponding products.

Synthesis of furoindolines. Furoindoline moiety is broadly found in the core structure of biologically active compounds and natural products $^{37-44}$. Considering that oxindole-3-acetates are versatile building blocks for constructing heterocycle-fused indolines ${ }^{45,46}$, we decided to apply the above method to the preparation of furoindoline derivatives. As shown in Fig. 6, by treatment of $\mathrm{N}$ arylacrylamides 7 and ethyl chlorooxoacetate $\mathbf{2 a}$ under the optimal conditions, followed by reduction with $\mathrm{LiAlH}_{4}$ at $0{ }^{\circ} \mathrm{C}$, furoindoline 9 was obtained as expected with excellent diastereoselectivities ${ }^{45}$. This route was highly efficient, and a range of furoindoline derivatives was readily produced in only two steps from simple precursors. Additionally, $\mathrm{N}$-(4-methoxyphenyl)- $N$-methylmethacrylamide reacted with ethyl chlorooxoacetate $2 \mathrm{a}$ under the standard conditions, giving rise to the desired tricyclic furoindoline $\mathbf{9 m}$, which could be readily converted into bioactive alkaloid physovenine in two steps ${ }^{37,38}$. In contrast to previous reports for the synthesis of physovenine, including Sharpless epoxidation ${ }^{39}$, Grignard reaction ${ }^{40}$, Diels-Alder reaction ${ }^{41}$, catalytic asymmetric Heck reaction ${ }^{42}$, intramolecular Michael addition ${ }^{43}$, and [3,3]-sigmatropic rearrangement ${ }^{44}$, this method was much better from the viewpoint of atom- and step-economy.

Synthetic application. We next applied this methodology to the concise synthesis of expensive dihydronaphthalene derivative $[5 \mathrm{~g} /$ $¥ 37,438$; supplier: Biofount], which is an important precursor for a wide range of biorelevant molecules ${ }^{47}$. In contrast to the conventional routes ${ }^{48,49}$, our method not only decreased the step count but also simplified the operation greatly (Fig. 7a). Furthermore, this strategy was utilized in the formal synthesis of marketed drug ozagrel, which was an antiplatelet drug and marketed in Japan in 198950-52. As shown in Fig. 5, this alkoxycarbonylation reaction enabled us to access key compound $\mathbf{6 i}$, which could be subsequently subjected to the substitution reaction with imidazole providing product $10 \mathbf{i}$ in $70 \%$ yield. An additional hydrolysis of compound 10i would afford ozagrel (Fig. 7b) ${ }^{52}$. Overman demonstrated that methoxycarbonyl radical could react with electron-deficient olefins

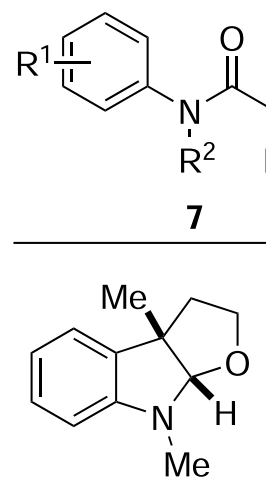

9a, 73\% yield<smiles>CC12CCOC1N1CCCCc3cccc2c31</smiles>

9e, $65 \%$ yield<smiles>CN1c2c(ccc3ccccc23)C2(C)CCOC12</smiles>

9i, $65 \%$ yield<smiles>CN1c2ccc(F)cc2C2(C)CCOC12</smiles>

9f, $60 \%$ yield<smiles>CCN1c2ccccc2C2(C)CCOC12</smiles>

9j, 68\% yield
$\operatorname{Ir}(\mathrm{ppy})_{3}(2 \mathrm{~mol} \%)$ 2,6-lutidine (2.0 equiv)

DMF, $40^{\circ} \mathrm{C}$, blue LEDs then $\mathrm{LiAlH}_{4}, \mathrm{THF}, \mathrm{O}^{\circ} \mathrm{C}, 2 \mathrm{~h}$<smiles>[R]N1c2cc[R1]cc2C2([R])CCO[C@H]12</smiles><smiles>CN1c2ccc(C(C)(C)C)cc2C2(C)CCCC12</smiles>

9c, $62 \%$ yield

9d, $68 \%$ yield<smiles>CN1c2ccc(Cl)cc2C2(C)CCOC12</smiles><smiles>CN1c2ccc(C(F)(F)F)cc2C2(C)CCOC12</smiles>

$9 g, 63 \%$ yield

9h, $53 \%$ yield<smiles>CCCN1c2ccccc2C2(C)CCOC12</smiles><smiles>CN1c2ccccc2C2(Br)CCOC12</smiles>

9k, 54\% yield

9l, 71\% yield<smiles>COc1ccc2c(c1)C1(C)CCOC1N2C</smiles>

$9 m, 46 \%$ yield<smiles>CNC(=O)Oc1ccc2c(c1)C1(C)CCOC1N2C</smiles>

(士)-Physovenine

Fig. 6 Synthesis of furoindoline derivatives. Isolated yields based on $\mathrm{N}$-arylacrylamide 7 
previous route: 6 steps, $35 \%$ yield $(6 q)$

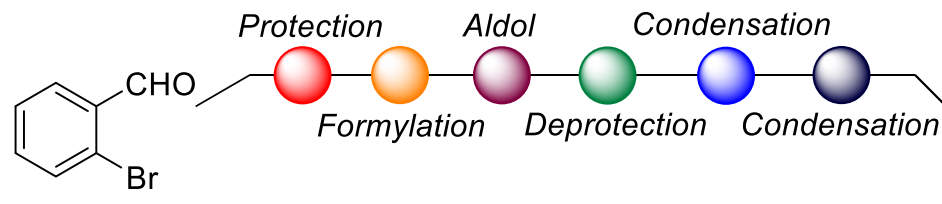

this work: $55 \%$ yield $(6 q)$

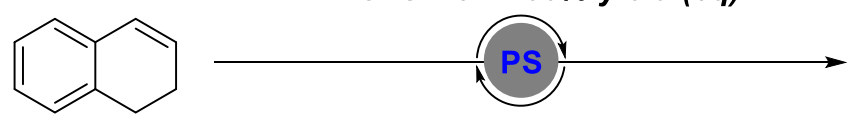

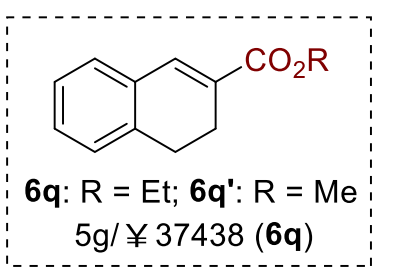

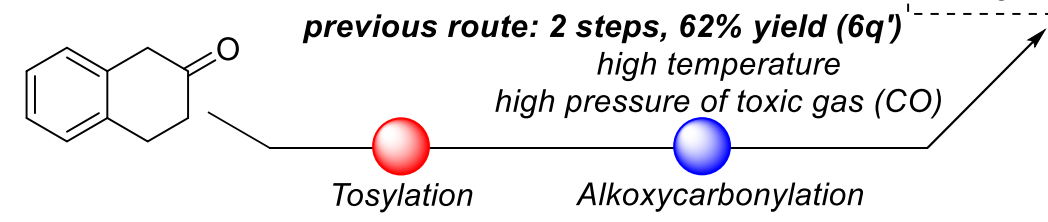<smiles>CCOC=Cc1ccc(CCl)cc1</smiles>

$6 \mathbf{i}$

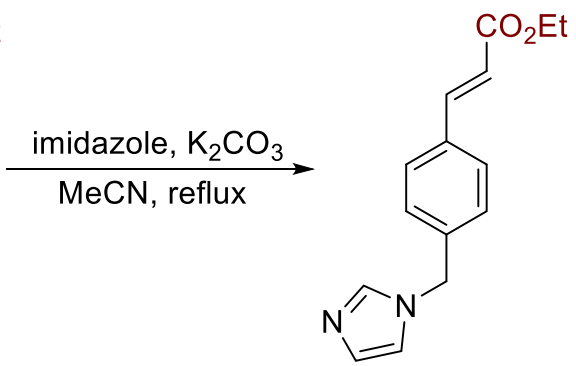

$10 \mathrm{i}, 70 \%$ yield<smiles>O=C(O)/C=C/c1ccc(Cn2ccnc2)cc1</smiles>

marketed drug: ozagrel

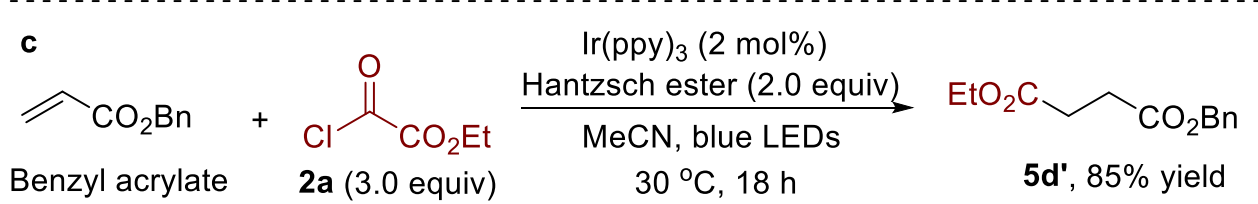

Fig. 7 Synthetic application. a Synthesis of expensive dihydronaphthalene derivative. b Formal synthesis of marketed drug ozagrel. c Synthesis of 1,4dicarbonyl compound.

to afford 1,4-dicarbonyl compounds ${ }^{13}$. We next applied our methodology to this transformation. As expected, coupling of ethyl chlorooxoacetate 2a (3.0 equiv) with benzyl acrylate in the presence of $\operatorname{Ir}(\mathrm{ppy})_{3}(2 \mathrm{~mol} \%)$ and diethyl 1,4-dihydro-2,6-dimethyl-3,5pyridinedicar-boxylate (2.0 equiv) in $\mathrm{MeCN}$ with blue LED irradiation at $30^{\circ} \mathrm{C}$ gave rise to 1,4 -dicarbonyl compound $\mathbf{5 d}$ ' in $85 \%$ yield (Fig. 7c).

Mechanistic studies. To elucidate the possible reaction mechanism, a radical clock experiment with (1-cyclopropylvinyl) benzene $1 \mathbf{x}$ as the substrate was preformed, and a ring-opening product was obtained as expected (Fig. 8a). This result clearly demonstrated the involvement of an alkoxycarbonyl radical. Additionally, a radical trapping experiment with the addition of 2,2,6,6-tetramethyl-1-piperidyloxy (TEMPO) showed that the related alkoxycarbonyl-TEMPO product was confirmed through gas chromatography-mass spectrometry (for details, see Supplementary Information). It is noteworthy that the presence of 2,6lutidine was significant for the success of these transformations. As mentioned above, both photosensitizer and visible light were necessary for this alkoxycarbonylation process (Table 1, entries 9 and 10). Thus, these results could rule out the ethyl chlorooxoacetate activation by the formation of electron-donor-acceptor complex ${ }^{53}$. As shown in Fig. 9b, the presence of 2,6-lutidine enhanced the reduction potential of ethyl chlorooxoacetate $\mathbf{2 a}$ from $E_{\mathrm{p}}(\mathbf{2 a})=-1.23 \mathrm{~V}$ vs. $\mathrm{Ag} / \mathrm{AgCl}$ to $E_{\mathrm{p}}(\mathbf{2} \mathbf{a}+2,6$-lutidine $)=$ $-1.09 \mathrm{~V}$ vs. $\mathrm{Ag} / \mathrm{AgCl} .{ }^{1} \mathrm{H}$ NMR studies showed a critical downfield shift of 2,6-lutidine protons after the addition of ethyl chlorooxoacetate 2a (for details, see Supplementary Fig. 4), indicating the generation of acyl pyridinium salt I-2a. The possible structure of I-2a is shown in Fig. 9. These results implied that there was no $\pi$ conjugation between the aromatic ring and acyl plane. Stern-Volmer experiments revealed that ethyl chlorooxoacetate $\mathbf{2 a}$ and acyl pyridinium salt I-2a could quench the excited photocatalyst, but alkene and 2,6-lutidine could not. The quenching constant for ${ }^{*} \operatorname{Ir}(\mathrm{ppy})_{3}$ with ethyl chlorooxoacetate $\mathbf{2 a}$ was determined as $k_{\mathrm{q}}=1.70 \times 10^{8} \mathrm{M}^{-1} \mathrm{~s}^{-1}$, which was 1.38 times faster than the reaction of $* \operatorname{Ir}(\mathrm{ppy})_{3}$ with $\mathbf{I}-2 \mathrm{a}$. We speculated that the unique three-dimensional structure of I-2a might influence the single electron transfer from the excited photocatalyst to I-2a. Notably, the addition of $\mathrm{Cl}^{-}$would slightly improve the yield of 3a from 3 to 20\% (Fig. 8d). This result suggested the feasibility of carbon cation pathway. The quantum yields of these reactions were determined to be $1.11,1.33$, and 9.98 , showing that the extended radical-chain reactions were possible. Moreover, bond dissociation energy of $\mathrm{C}-\mathrm{H}$ bond could reflect the stability of 
a Radical clock

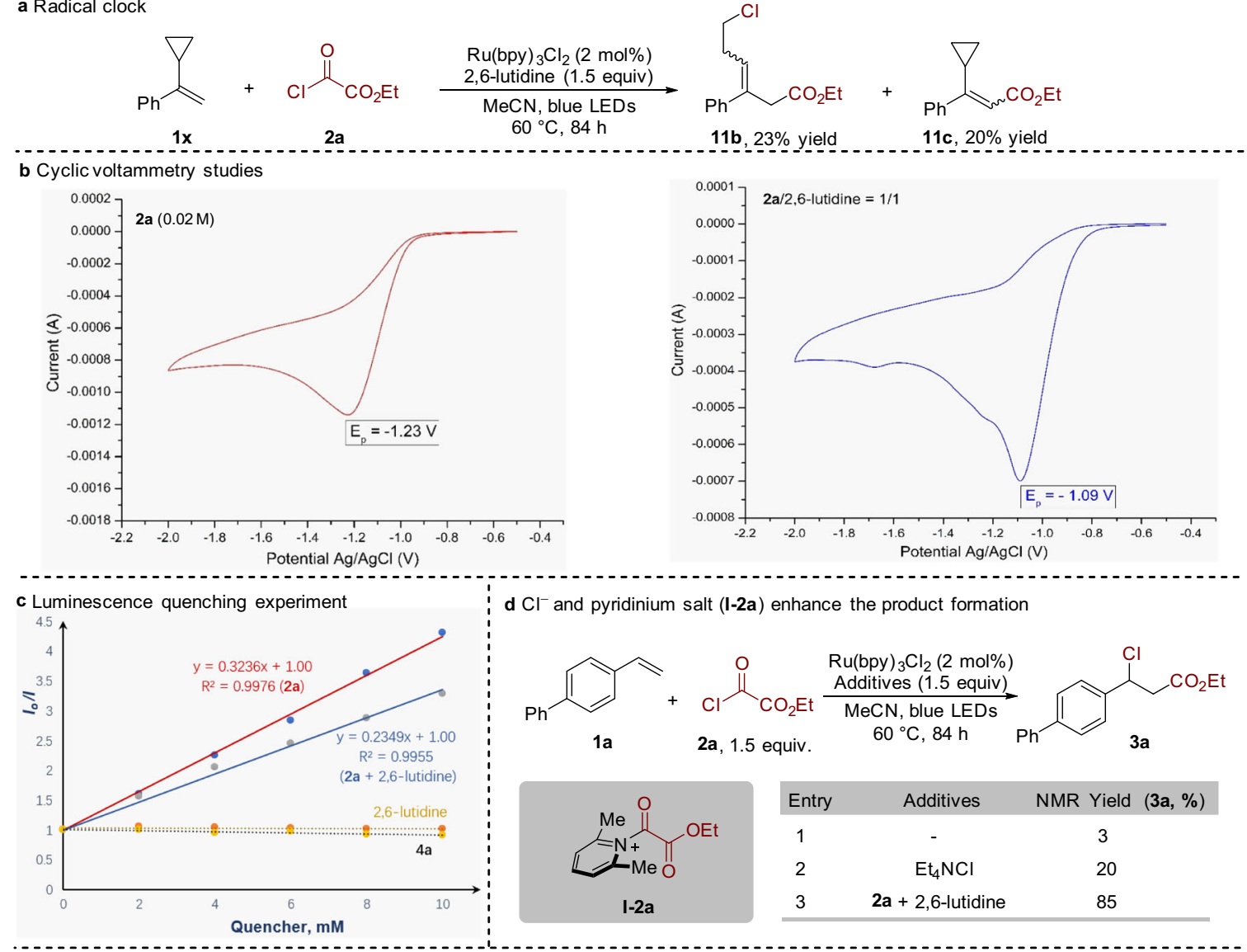

e Free-energy reaction profiles ( $\mathrm{kcal} / \mathrm{mol}$ ) calculated with the SMD (acetonitrile) M062X/6-31+G(d) level at $303 \mathrm{~K}$.

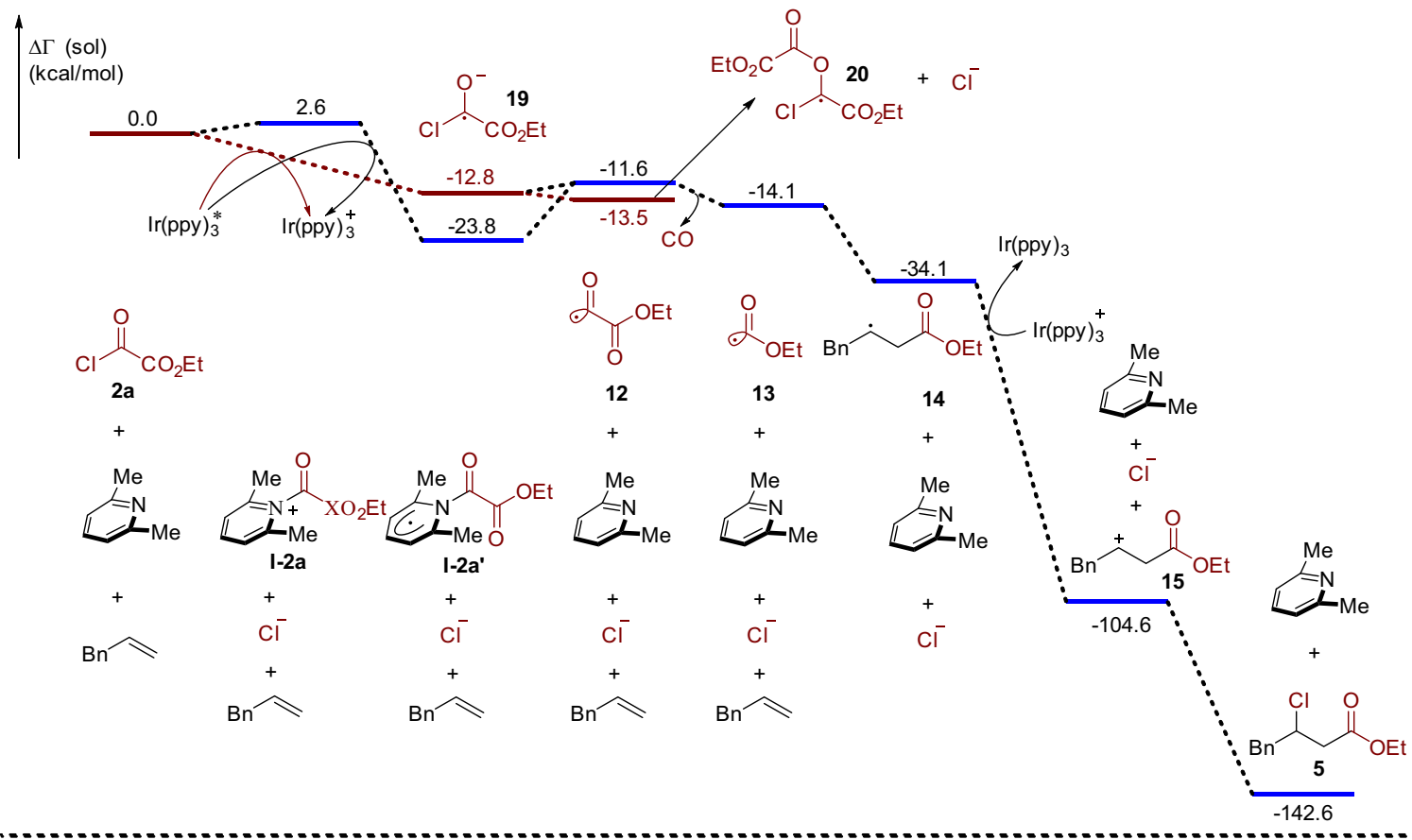

Fig. 8 Mechanistic studies. a Radical clock experiment. b Cyclic voltammetric studies. c Luminescence quenching experiment. d $\mathrm{Cl}^{-}$and pyridinium salt (I-2a) enhance the product formation. e Free-energy reaction profiles ( $\mathrm{kcal} \mathrm{mol}^{-1}$ ) calculated with the SMD (acetonitrile) M062X/6-31 + G(d) level at $303 \mathrm{~K}$. 


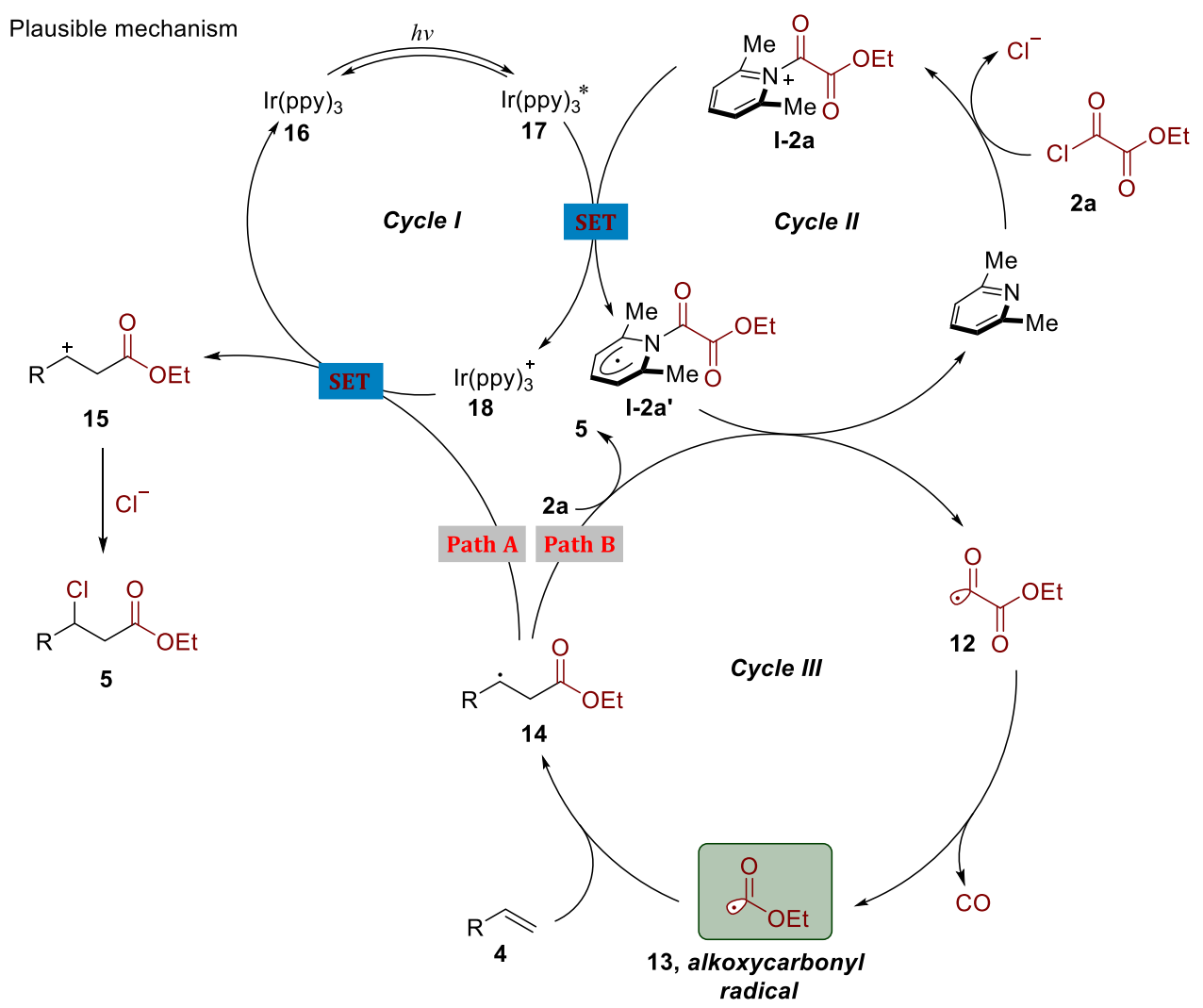

Fig. 9 Plausible mechanism for photocatalyzed alkoxycarbonylchlorination. Cycle I: photocatalytic cycle. Cycle II: 2,6-lutidine-initiated catalytic cycle with compound 2a. Cycle III: chain pathway for the generation of alkoxycarbonyl radical $\mathbf{1 3}$ via decarbonylation.

carbon radicals. The $\mathrm{C}-\mathrm{H}$ bond dissociation energy of $\mathrm{MeOC}(\mathrm{O})-\mathrm{H}$ and ${ }^{\mathrm{t}} \mathrm{Bu}-\mathrm{H}$ are $95.4^{54}$ and $95.6 \mathrm{kcal} \mathrm{mol}^{-155}$, respectively, and the stability of alkoxycarbonyl radical might be similar to the tertiary carbon radical.

In order to shed more light on the reaction mechanism, especially the role of 2,6-lutidine, density functional theory (DFT) calculations were carried out with the Gaussian 09 software package ${ }^{56-58}$. The calculation details were provided in the Supplementary Information. As shown in Fig. 9e, the whole reaction was thermodynamically favorable and the driving force for this transformation was the extrusion of carbon monoxide, the generation of stable alkoxycarbonyl radical 13, and subsequent reaction with alkene to afford alkyl radical $\mathbf{1 4}$. Concerning the formation of key intermediate 12, though the generation of acyl pyridinium salt I-2a was a little bit endothermic, the formation of I-2a' via reduction of $\mathbf{I}-\mathbf{2 a}$ by highly reducing species ${ }^{*} \operatorname{Ir}(\mathrm{ppy})_{3}$ was more thermodynamically favored compared to the direct formation of 19 without partition of 2,6-lutidine. Additionally, anion radical 19 could react with compound 2a to deliver the undesired alkyl radical 20. Thus, 2,6lutidine might facilitate the transformation relative to no participation of 2,6-lutidine. Moreover, Stern-Volmer experiments have demonstrated that the step to generate anion radical 19 is kinetically favorable. Hence, raising the equivalent of 2,6lutidine would facilitate the generation of the I-2a' and suppress the formation of anion radical 19. As shown in Supplementary Fig. 15, DFT calculations were also applied to study the side reaction of ethoxycarbonyl radical and ethyl chlorooxoacetate to generate radical 12 and ethyl carbonochloridate. The reaction free energy was $0.6 \mathrm{kcal} \mathrm{mol}^{-1}$, while the reaction free energy of methoxycarbonyl radical and methyloxalyl chloride was only $0.1 \mathrm{kcal} \mathrm{mol}^{-1}$. According to Arrhenius equation, the side reaction of the latter was more than the former. This might contribute to the low yield of methyloxalyl chloride compared to ethyloxalyl chloride (3b vs. $3 \mathbf{r}$ ).

On the basis of the above experimental results and previous reports ${ }^{59}$, a plausible reaction mechanism is proposed in Fig. 9. Excitation of photosensitizer $\operatorname{Ir}(\mathrm{ppy})_{3} \mathbf{1 6}$ with blue light would generate a long-lived excited ${ }^{*} \operatorname{Ir}(\mathrm{ppy})_{3}(\tau=1.9 \mu \mathrm{s})^{59}$. Meanwhile, 2,6-lutidine would condense with ethyl chlorooxoacetate 2 a to form acyl pyridinium salt I-2a. The highly reducing species ${ }^{*} \operatorname{Ir}(\mathrm{ppy})_{3} 17\left(\mathrm{E}_{1 / 2}\left[\operatorname{Ir}(\mathrm{ppy})_{3}+/{ }^{*} \operatorname{Ir}(\mathrm{ppy})_{3}\right]=-1.73 \mathrm{~V}\right.$ vs. saturated calomel electrode) would reduce intermediate $\mathbf{I}-2 \mathbf{a}$ leading to radical intermediate $\mathbf{I}-2 \mathbf{a}^{\prime}$ and $\operatorname{Ir}(\mathrm{ppy})_{3}{ }^{+} \mathbf{1 8}$. The radical intermediate I-2a' would undergo $\mathrm{C}-\mathrm{N}$ homolysis to form acyl radical intermediate 12 with the elimination of 2,6-lutidine ${ }^{60,61}$. Acyl radical 12 would then undergo decarbonylation, giving rise to alkoxycarbonyl radical $13^{62,63}$. The driving force for this transformation is the extrusion of carbon monoxide and the generation of stable alkoxycarbonyl radical. This ambiphilic radical 13 could react with an alkene to afford alkyl radical 14, which would be readily oxidized by $\operatorname{Ir}(\text { ppy })_{3}+18$ to regenerate ground-state photocatalyst $\mathbf{1 6}$ and carbocation intermediate $\mathbf{1 5}$. This carbocation intermediate $\mathbf{1 5}$ would be attacked by chloride anion leading to the desirable $\beta$-chloro ester 5 (path A). A competitive chain pathway could not be excluded (path B). Alkyl radical 14 would abstract chlorine atom from ethyl chlorooxoacetate $\mathbf{2 a}$ to produce the target product $\mathbf{5}$ and regenerate acyl radical intermediate $\mathbf{1 2}$.

\section{Discussion}

In summary, we have described the generation and application of alkoxycarbonyl radicals under photoredox catalysis from alkyloxalyl chlorides, generated in situ from the corresponding alcohols and oxalyl chloride. This photocatalytic strategy to introduce both the desired ester group and a versatile electrophile at the $\beta$ - 
position of ester group is quite useful for the preparation of significant compounds, due to its complementary reactivity. Additionally, a formal $\beta$-selective alkene alkoxycarbonylation is described. With this approach, a variety of oxindole-3-acetates and furoindolines are prepared in good-to-excellent yields through alkoxycarbonylation/cyclization with $\mathrm{N}$-arylacrylamides under mild conditions. Additionally, this strategy can be compatible with the derivatization of alcohol-containing biologically active molecules. A more concise formal synthesis of $( \pm)$-physovenine is accomplished as well. All these results further demonstrate the potential of employing native functionality to access structural analogs and to provide the late-stage functionalization.

\section{Methods}

General procedure for the synthesis of compound 3. Substrate $\mathbf{1}(0.2 \mathrm{mmol})$, alkyloxyoxalyl chloride $2(0.6 \mathrm{mmol})$, and 2,6-lutidine $(32.1 \mathrm{mg}, 0.3 \mathrm{mmol})$ were added to a solution of $\mathrm{Ru}(\mathrm{bpy}){ }_{3} \mathrm{Cl}_{2}(3.0 \mathrm{mg}, 2 \mathrm{~mol} \%)$ in dry $\mathrm{MeCN}(4.0 \mathrm{~mL})$ at $25^{\circ} \mathrm{C}$. The heterogeneous mixture was degassed by three cycles of freeze-pump-thaw and then placed in the irradiation apparatus equipped with blue LEDs. The resulting mixture was stirred at $60^{\circ} \mathrm{C}$ for $84 \mathrm{~h}$. Upon completion of the reaction, the mixture was diluted with ethyl acetate $(30 \mathrm{~mL})$, washed with brine $(10 \times 3 \mathrm{~mL})$, and dried with $\mathrm{Na}_{2} \mathrm{SO}_{4}$. After evaporation of the solvent, the crude product was purified by column chromatography on silica gel to afford the desired product 3 .

\section{General procedure for the synthesis of compound 5 or 5'. Substrate 4} $(0.2 \mathrm{mmol})$, alkyloxyoxalyl chloride $\mathbf{2 a}(218.4 \mathrm{mg}, 1.6 \mathrm{mmol})$, and 2,6-lutidine $(42.8 \mathrm{mg}, 0.4 \mathrm{mmol})$ were added to a solution of $\operatorname{Ir}(\mathrm{ppy})_{3}(6.54 \mathrm{mg}, 5 \mathrm{~mol} \%)$ in dry $\mathrm{MeCN}(4.0 \mathrm{~mL})$ at $25^{\circ} \mathrm{C}$. The heterogeneous mixture was degassed by three cycles of freeze-pump-thaw and then placed in the irradiation apparatus equipped with blue LEDs. The resulting mixture was stirred at $30^{\circ} \mathrm{C}$ for $60 \mathrm{~h}$. Upon completion of the reaction, the mixture was diluted with ethyl acetate $(30 \mathrm{~mL})$, washed with brine $(10 \times 3 \mathrm{~mL})$, and dried with $\mathrm{Na}_{2} \mathrm{SO}_{4}$. The solvent was evaporated, and the crude product was purified by column chromatography on silica gel to afford the desired product $\mathbf{5}$ or $\mathbf{5}^{\prime}$.

General procedure for the synthesis of compound 6. Substrate $1(0.2 \mathrm{mmol})$, chlorooxoacetate $2 \mathrm{a}(81.9 \mathrm{mg}, 0.6 \mathrm{mmol})$, and 2,6 -lutidine $(32.1 \mathrm{mg}, 0.3 \mathrm{mmol})$ were added to a solution of $\mathrm{Ru}(\mathrm{bpy})_{3} \mathrm{Cl}_{2}(3.0 \mathrm{mg}, 2 \mathrm{~mol} \%)$ in dry $\mathrm{MeCN}(4.0 \mathrm{~mL})$ at $25^{\circ} \mathrm{C}$. The heterogeneous mixture was degassed by three cycles of freeze-pump-thaw and then placed in the irradiation apparatus equipped with blue LEDs. The resulting mixture was stirred at $60^{\circ} \mathrm{C}$ for $84 \mathrm{~h}$. Upon completion of the reaction, 1,8-diazabicyclo[5.4.0] undec-7-ene $(152.2 \mathrm{mg}, 1.0 \mathrm{mmol})$ was added and the mixture was stirred at $25^{\circ} \mathrm{C}$ for $0.5 \mathrm{~h}$. The mixture was diluted with ethyl acetate $(30 \mathrm{~mL})$, washed with brine $(10 \times 3 \mathrm{~mL})$, and dried with $\mathrm{Na}_{2} \mathrm{SO}_{4}$. The solvent was then evaporated, and the crude product was purified by column chromatography on silica gel to afford the desired product $\mathbf{6}(\mathbf{6 a}-\mathbf{6 n}$ and $\mathbf{6 q})$.

Substrate $4(0.2 \mathrm{mmol})$, alkyloxyoxalyl chloride $2 \mathrm{a}(218.4 \mathrm{mg}, 1.6 \mathrm{mmol})$, and 2,6-lutidine ( $42.8 \mathrm{mg}, 0.4 \mathrm{mmol}$ ) were added to a solution of $\operatorname{Ir}(\mathrm{ppy})_{3}(6.54 \mathrm{mg}$, $5 \mathrm{~mol} \%)$ in dry MeCN $(4.0 \mathrm{~mL})$ at $25^{\circ} \mathrm{C}$. The heterogeneous mixture was degassed by three cycles of freeze-pump-thaw and then placed in the irradiation apparatus equipped with blue LEDs. The resulting mixture was stirred at $30^{\circ} \mathrm{C}$ for $60 \mathrm{~h}$. Upon completion of the reaction, the mixture was diluted with ethyl acetate $(30 \mathrm{~mL})$, washed with brine $(10 \times 3 \mathrm{~mL})$, and dried with $\mathrm{Na}_{2} \mathrm{SO}_{4}$. After evaporation of the solvent, the crude product was dissolved in tetrahydrofuran (THF; $4 \mathrm{~mL}$ ) and DBU $(152.2 \mathrm{mg}, 1.0 \mathrm{mmol})$ was added. The reaction mixture was stirred at $25^{\circ} \mathrm{C}$ for $0.5 \mathrm{~h}$. Then the mixture was diluted with ethyl acetate $(30 \mathrm{~mL})$, washed with brine $(10 \times 3 \mathrm{~mL})$, and dried with $\mathrm{Na}_{2} \mathrm{SO}_{4}$. After evaporation of the solvent, the crude product was purified by column chromatography on silica gel to afford the desired product $6(60$ and $6 \mathrm{p})$.

General procedure for the synthesis of compound 8. Substrate $7(0.2 \mathrm{mmol})$, alkyloxyoxalyl chloride $2(0.6 \mathrm{mmol})$, and 2,6-lutidine $(42.8 \mathrm{mg}, 0.4 \mathrm{mmol})$ were added to a solution of $\operatorname{Ir}(\mathrm{ppy})_{3}(2.62 \mathrm{mg}, 2 \mathrm{~mol} \%)$ in dry DMF $(4.0 \mathrm{~mL})$ at $25^{\circ} \mathrm{C}$. The heterogeneous mixture was degassed by three cycles of freeze-pump-thaw and then placed in the irradiation apparatus equipped with blue LEDs. The resulting mixture was stirred at $40^{\circ} \mathrm{C}$ until the starting material was completely consumed as monitored by thin-layer chromatography (TLC). Upon completion of the reaction, the mixture was diluted with ethyl acetate $(30 \mathrm{~mL})$, washed with brine $(10 \times 3 \mathrm{~mL})$, and dried with $\mathrm{Na}_{2} \mathrm{SO}_{4}$. After evaporation of the solvent, the crude product was purified by column chromatography on silica gel to afford the desired product 8 .

General procedure for the synthesis of compound 9. Substrate $7(0.2 \mathrm{mmol})$, ethyl chlorooxoacetate $2 \mathrm{a}(81.9 \mathrm{mg}, 0.6 \mathrm{mmol})$, and 2,6 -lutidine $(42.8 \mathrm{mg}$, $0.4 \mathrm{mmol})$ were added to a solution of $\operatorname{Ir}(\mathrm{ppy})_{3}(2.62 \mathrm{mg}, 2 \mathrm{~mol} \%)$ in dry DMF $(4.0 \mathrm{~mL})$ at $25^{\circ} \mathrm{C}$. The heterogeneous mixture was degassed by three cycles of freeze-pump-thaw and then placed in the irradiation apparatus equipped with blue LEDs. The resulting mixture was stirred at $40{ }^{\circ} \mathrm{C}$ until the starting material was completely consumed as monitored by TLC. Upon completion of the reaction, the mixture was diluted with ethyl acetate $(30 \mathrm{~mL})$, washed with brine $(10 \times 3 \mathrm{~mL})$, and dried with $\mathrm{Na}_{2} \mathrm{SO}_{4}$. After evaporation of the solvent, the crude product was used in the following step without further purification. To a solution of crude product in THF $(4.0 \mathrm{~mL})$ at $0{ }^{\circ} \mathrm{C}$ was added $\mathrm{LiAlH}_{4}(38 \mathrm{mg}, 1.0 \mathrm{mmol})$ in small portions under nitrogen atmosphere. The reaction mixture was stirred at $0{ }^{\circ} \mathrm{C}$ for $2 \mathrm{~h}$, and then the reaction was quenched with the addition of brine $(15 \mathrm{~mL})$ and diluted with EtOAc $(30 \mathrm{~mL})$. The combined organic layers were washed with brine $(3 \times 10 \mathrm{~mL})$, dried over $\mathrm{Na}_{2} \mathrm{SO}_{4}$, filtered, and concentrated under reduced pressure. The resulting residue was purified by flash column chromatography with gradient eluents $(n$-hexane/ethyl acetate $=20 / 1)$ to provide compound $\mathbf{9}$.

\section{Data availability}

The data that support the findings of this study are available within the paper and its Supplementary Information files. Raw data are available from the corresponding author on reasonable request. Materials and methods, experimental procedures, characterization data, ${ }^{1} \mathrm{H}$ and ${ }^{13} \mathrm{C}$ NMR spectra, and mass spectrometric data are available in the Supplementary Information.

Received: 14 March 2021; Accepted: 19 August 2021; Published online: 07 September 2021

\section{References}

1. Noda, K., Chang, H.-P., Takahashi, I., Kinoshita, Z. \& Kawamoto, T. Effects of the anabolic steroid nandrolone phenylpropionate on craniofacial growth in rats. J. Morphol. 220, 25-33 (1994).

2. Ferreira, J. P. et al. Renal function stratified dose comparisons of eplerenone versus placebo in the EMPHASIS-HF trial. Eur. J. Heart Fail. 21, 345-351 (2019).

3. Radivojevic, J. et al. Polyhydroxyalkanoate-based 3-hydroxyoctanoic acid and its derivatives as a platform of bioactive compounds. Appl. Microbiol. Biotechnol. 100, 161-172 (2016).

4. Dauban, P., Darses, B. \& Jarvis, A. in Comprehensive Organic Synthesis (eds Knochel, P. \& Molander, G. A.) Ch. 7 (Elsevier, 2014).

5. Kiss, G. Palladium-catalyzed Reppe carbonylation. Chem. Rev. 101, 3435-3456 (2001).

6. Eastham, G. R. A catalyst system suitable for carbonylating ethylenically unsaturated compounds. World patent WO2004014552A1 (2004).

7. Li, H. et al. The Scope and mechanism of palladium-catalysed Markovnikov alkoxycarbonylation of alkenes. Nat. Chem. 8, 1159-1166 (2016).

8. Yu, W.-Y., Sit, W. N., Lai, K.-M., Zhou, Z. Y. \& Chan, A. S. C. Palladiumcatalyzed oxidative ethoxycarbonylation of aromatic $\mathrm{C}-\mathrm{H}$ bond with diethyl azodicarboxylate. J. Am. Chem. Soc. 130, 3304-3306 (2008).

9. Trost, B. M., Waser, J. \& Meyer, A. Total synthesis of (-)-pseudolaric acid B. J. Am. Chem. Soc. 130, 16424-16434 (2008).

10. Kyne, S. H., Schiesser, C. H. \& Matsubarac, H. Multi-component orbital interactions during oxyacyl radical addition reactions involving imines and electron-rich olefins. Org. Biomol. Chem. 5, 3938-3943 (2007).

11. Taniguchi, T., Sugiura, Y., Zaimoku, H. \& Ishibashi, H. Iron-catalyzed oxidative addition of alkoxycarbonyl radicals to alkenes with carbazates and air. Angew. Chem. Int. Ed. 49, 10154-10157 (2010).

12. Zheng, M. et al. Visible-light-driven, metal-free divergent difunctionalization of alkenes using alkyl formates. ACS Catal. 11, 542-553 (2021).

13. Slutskyy, Y. \& Overman, L. E. Generation of the methoxycarbonyl radical by visible-light photoredox catalysis and its conjugate addition with electrondeficient olefins. Org. Lett. 18, 2564-2567 (2016).

14. Nawrat, C. C., Jamison, C. R., Slutskyy, Y., MacMillan, D. W. C. \& Overman L. E. Oxalates as activating groups for alcohols in visible light photoredox catalysis: formation of quaternary centers by redox-neutral fragment coupling. J. Am. Chem. Soc. 137, 11270-11273 (2015).

15. Xu, S.-M. et al. Aroyl chlorides as novel acyl radical precursors via visible-light photoredox catalysis. Org. Chem. Front. 4, 1331-1335 (2017).

16. Lei, Z. et al. $\beta$-Selective aroylation of activated alkenes by photoredox catalysis. Angew. Chem. Int. Ed. 58, 7318-7323 (2019).

17. Raviola, C., Protti, S., Ravelli, D. \& Fagnoni, M. Photogenerated acyl/ alkoxycarbonyl/carbamoyl radicals for sustainable synthesis. Green Chem. 21, 748-764 (2019).

18. Hell, S. M. et al. Silyl radical-mediated activation of sulfamoyl chlorides enables direct access to aliphatic sulfonamides from alkenes. J. Am. Chem. Soc. 142, 720-725 (2020).

19. Patra, T. et al. Palladium-catalyzed directed para $\mathrm{C}-\mathrm{H}$ functionalization of phenols. Angew. Chem. Int. Ed. 55, 7751-7755 (2016). 
20. Zhao, Y., Wang, G., Li, Y., Wang, S. \& Li, Z. Design, synthesis and insecticidal activities of novel N-oxalyl derivatives of neonicotinoid compound. Chin. J. Chem. 28, 475-479 (2010).

21. Bucher, G., Halupka, M., Kolano, C., Schade, O. \& Sander, W. Characterization of alkoxycarbonyl radicals by step-scan time-resolved infrared spectroscopy. Eur. J. Org. Chem. 2001, 545-552 (2001).

22. Camacho, D. M. et al. Morphology and growth of methyl stearate as a function of crystallization environment. Cryst. Growth Des. 17, 563-575 (2017).

23. Lu, Q. et al. Nematicidal effect of methyl palmitate and methyl stearate against meloidogyne incognita in bananas. J. Agric. Food Chem. 68, 6502-6510 (2020).

24. Pokorski, M., Marczak, M., Dymecka, A. \& Suchocki, P. Ascorbyl palmitate as a carrier of ascorbate into neural tissues. J. Biomed. Sci. 10, 193-198 (2003).

25. Yamazaki, Y. et al. Polycation liposomes, a novel nonviral gene transfer system, constructed from cetylated polyethylenimine. Gene Ther. 7, $1148-1155$ (2000).

26. Zhou, Y.-Y. et al. Two new tetralone glycosides from the green walnut husks of juglans mandshurica maxim. Nat. Prod. Res. 33, 2932-2938 (2019).

27. Dange, N. S., Jatoi, A. H., Robert, F. \& Landais, Y. Visible-light-mediated addition of phenacyl bromides onto cyclopropenes. Org. Lett. 19, 3652-3655 (2017).

28. Legoabe, L. J., Petzer, A. \& Petzer, J. P. $\alpha$-Tetralone derivatives as inhibitors of monoamine oxidase. Bioorg. Med. Chem. Lett. 24, 2758-2763 (2014).

29. Cheung, M. et al. Discovery of tetralones as potent and selective inhibitors of acylCoA: diacylglycerol acyltransferase 1. ACS Med. Chem. Lett. 9, 103-108 (2018).

30. Cernak, T., Dykstra, K. D., Tyagarajan, S., Vachal, P. \& Krska, S. W. The medicinal chemist's toolbox for late stage functionalization of drug-like molecules. Chem. Soc. Rev. 45, 546-576 (2016).

31. Poldy, J., Peakall, R. \& Barrow, R. A. Identification of the first alkenyl chiloglottone congener. Eur. J. Org. Chem. 2012, 5818-5827 (2012).

32. Konrádová, D., Kozubíková, H., Doležal, K. \& Pospišil, J. Microwave-assisted synthesis of phenylpropanoids and coumarins: total synthesis of osthol. Eur. J. Org. Chem. 2017, 5204-5213 (2017).

33. Kim, K. H., Lee, H. S., Kim, S. H., Kim, S. H. \& Kim, J. N. Construction of a tetracyclic butterfly-like scaffold: palladium-catalyzed Heck/arylation cascade. Chem. Eur. J. 16, 2375-2380 (2010).

34. Jiménez-Osés, G., Brockway, A. J., Shaw, J. T. \& Houk, K. N. Mechanism of alkoxy groups substitution by grignard reagents on aromatic rings and experimental verification of theoretical predictions of anomalous reactions. J. Am. Chem. Soc. 135, 6633-6642 (2013).

35. Zhang, S., Neumann, H. \& Beller, M. Synthesis of $\alpha, \beta$-unsaturated carbonyl compounds by carbonylation reactions. Chem. Soc. Rev. 49, 3187-3210 (2020).

36. Illidge, T. et al. Phase II study of gemcitabine and bexarotene (GEMBEX) in the treatment of cutaneous T-cell lymphoma. Br. J. Cancer 109, 2566-2573 (2013).

37. Kulkarni, M. G. et al. Total synthesis of ( \pm )-physovenine. Eur. J. Org. Chem. 2009, 3875-3877 (2009).

38. Chen, J.-Q., Wei, Y.-L., Xu, G.-Q., Liang, Y.-M. \& Xu, P.-F. Intramolecular $1,5-\mathrm{H}$ transfer reaction of aryl iodides through visible-light photoredox catalysis: a concise method for the synthesis of natural product scaffolds. Chem. Commun. 52, 6455-6458 (2016).

39. Sunazuka, T. et al. Total synthesis of (-)-physovenine from (-)-3ahydroxyfuroindoline. Tetrahedron Lett. 46, 1459-1461 (2005).

40. Morales-Ríos, M. S., Santos-Sánchez, N. F. \& Joseph-Nathan, P. Efficient formal total synthesis of physostigmine and physovenine: conformational analysis of key intermediates. J. Nat. Prod. 65, 136-141 (2002).

41. Node, M., Hao, X.-J., Nishide, K. \& Fuki, K. A formal asymmetric synthesis of calabar bean alkaloids. Chem. Pharm. Bull. 44, 715-719 (1994).

42. Matsuura, T., Overman, L. E. \& Poon, D. J. Catalytic asymmetric synthesis of either enantiomer of the calabar alkaloids physostigmine and physovenine. J. Am. Chem. Soc. 120, 6500-6503 (1998).

43. Horne, S., Taylor, N., Collins, S. \& Rodrigo, R. Rapid syntheses of some indole alkaloids of the calabar bean. J. Chem. Soc. Perkin Trans. 1 12, 3047-3051 (1991).

44. Tanaka, K., Taniguchi, T. \& Ogasawara, K. 7,7-Dimethyl-6,8dioxabicyclo[3.3.0] oct-3-en-2-one as a synthetic equivalent of ketodicyclopentadiene: a new route to $(-)$-physostigmine, $(-)$-physovenine, and (-)-aphanorphine. Tetrahedron Lett. 42, 1049-1052 (2001).

45. Xu, J., Liang, L., Zheng, H., Robin Chi, Y. \& Tong, R. Green oxidation of indoles using halide catalysis. Nat. Commun. 10, 4754-4764 (2019).

46. Chen, M. et al. Palladium-catalyzed enantioselective heck carbonylation with a monodentate phosphoramidite ligand: asymmetric synthesis of $(+)$-physostigmine, $(+)$-physovenine, and (+)-folicanthine. Angew. Chem. Int. Ed. 59, 12199-12205 (2020).
47. Hattori, K. et al. Discovery of diphenylcarbamate derivatives as highly potent and selective ip receptor agonists: orally active prostacyclin mimetics. part 3. Bioorg. Med. Chem. Lett. 15, 3091-3095 (2005).

48. te Grotenhuis, C. et al. Catalytic 1,2-dihydronaphthalene and E-aryl-diene synthesis via CoIII-carbene radical and o-quinodimethane intermediates. Chem. Sci. 8, 8221-8230 (2017).

49. Reeves, D. C. et al. Palladium catalyzed alkoxy- and aminocarbonylation of vinyl tosylates. Org. Lett. 13, 2495-2497 (2011).

50. Loo, M. H., Egan, D. \& Vaughan, E. D. The effect of the thromboxane A2 synthesis inhibitor OKY-046 on renal function in rabbits following release of unilateral ureteral obstruction. J. Urol. 137, 571-576 (1987).

51. Hiraku, S. et al. Pharmacological studies on the TXA2 synthetase inhibitor (E)-3-[p(1H-lmidazol-1-ylmethyl)phenyl]-2-propenoic acid (OKY-046). Jpn. J. Pharmacol. 41, 393-401 (1986).

52. Nie, X.-L., Hu, C.-Y., Huang, C.-G. \& Shang-Guan, X.-C. Synthesis and crystal structure of a three-dimensional cobalt coordination polymer assembled by ozagrel ligands. Chin. J. Struct. Chem. 34, 117-122 (2015).

53. Yuan, Y., Majumder, S., Yang, M. \& Guo, S. Recent advances in catalyst-free photochemical reactions via electron-donor-acceptor (EDA) complex process. Tetrahedron Lett. 61, 151506-151520 (2020).

54. Budai, B., Leclair, A., Wang, Q. \& Zhu, J. Copper-catalyzed 1,2-methoxy methoxycarbonylation of alkenes with methyl formate. Angew. Chem. Int. Ed. 58, 10305-10309 (2019).

55. Xu, W., Wang, W., Liu, T., Xie, J. \& Zhu, C. Late-stage trifluoromethylthiolation of benzylic C-H bonds. Nat. Commun. 10 4867-4874 (2019).

56. Becke, A. D. Density-functional thermochemistry. III. The role of exact exchange. J. Chem. Phys. 98, 5648-5652 (1993).

57. Stephens, P. J., Devlin, F. J., Chabalowski, C. F. \& Frisch, M. J. Ab initio calculation of vibrational absorption and circular dichroism spectra using density functional force fields. J. Phys. Chem. 98, 11623-11627 (1994).

58. M. J. Frisch, et al. Gaussian 09, Revision D.01 (Gaussian, Inc., 2009).

59. Prier, C. K., Rankic, D. A. \& MacMillan, D. W. C. Visible light photo-redox catalysis with transition metal complexes: applications in organic synthesis. Chem. Rev. 113, 5322-5363 (2013).

60. Miyazawa, K., Ochi, R., Koike, T. \& Akita, M. Photoredox radical C-H oxygenation of aromatics with aroyloxylutidinium salts. Org. Chem. Front. 5, 1406-1410 (2018).

61. Moon, Y. et al. Visible light induced alkene aminopyridylation using $\mathrm{N}$-aminopyridinium salts as bifunctional reagents. Nat. Commun. 10, 4117-4125 (2019).

62. Huang, H., Zhang, G. \& Chen, Y. Dual hypervalent iodine(III) reagents and photoredox catalysis enable decarboxylative ynonylation under mild conditions. Angew. Chem. Int. Ed. 54, 7872-7876 (2015).

63. Bath, S., Laso, N. M., Lopez-Ruiz, H., Quiclet-Sire, B. \& Zard, S. Z. A practical access to acyl radicals from acyl hydrazides. Chem. Commun. 204-205 (2003).

\section{Acknowledgements}

Financial support from National Natural Science Foundation of China (No. 21871053), the Leading Innovative and Entrepreneur Team Introduction Program of Zhejiang (No. 2019R01005), and the Open Research Fund of School of Chemistry and Chemical Engineering, Henan Normal University (2020ZD04) is gratefully acknowledged.

\section{Author contributions}

J.-Q.C. and J.W. conceived and supervised the whole project and wrote the paper with input from all authors. J.-Q.C., X.T., and J.W. designed and discussed the experiments. J.-Q.C., X.T., Q.T., K.L., L.X., S.W., and M.J. performed and analyzed the experiments. Z.L. performed the DFT calculations.

\section{Competing interests}

The authors declare no competing interests.

\section{Additional information}

Supplementary information The online version contains supplementary material available at https://doi.org/10.1038/s41467-021-25628-x.

Correspondence and requests for materials should be addressed to J.-Q.C., Z.L. or J.W

Peer review information Nature Communications thanks the anonymous reviewer(s) for their contribution to the peer review of this work.

Reprints and permission information is available at http://www.nature.com/reprints

Publisher's note Springer Nature remains neutral with regard to jurisdictional claims in published maps and institutional affiliations. 
(c) (i) Open Access This article is licensed under a Creative Commons Attribution 4.0 International License, which permits use, sharing, adaptation, distribution and reproduction in any medium or format, as long as you give appropriate credit to the original author(s) and the source, provide a link to the Creative Commons license, and indicate if changes were made. The images or other third party material in this article are included in the article's Creative Commons license, unless indicated otherwise in a credit line to the material. If material is not included in the article's Creative Commons license and your intended use is not permitted by statutory regulation or exceeds the permitted use, you will need to obtain permission directly from the copyright holder. To view a copy of this license, visit http://creativecommons.org/ licenses/by/4.0/.

(C) The Author(s) 2021 